\title{
An overview of chemical enhanced oil recovery: recent advances and prospects
}

\author{
Afeez O. Gbadamosi ${ }^{1} \cdot$ Radzuan Junin ${ }^{1} \cdot$ Muhammad A. Manan $^{1} \cdot$ Augustine Agi ${ }^{1}$. Adeyinka S. Yusuff ${ }^{2}$
}

Received: 6 January 2019 / Accepted: 9 April 2019 / Published online: 29 April 2019

(c) The Author(s) 2019

\begin{abstract}
Despite the progress made on renewable energy, oil and gas remains the world's primary energy source. Meanwhile, large amounts of oil deposits remain unrecovered after application of traditional oil recovery methods. Chemical enhanced oil recovery (EOR) has been adjudged as an efficient oil recovery technique to recover bypassed oil and residual oil trapped in the reservoir. This EOR method relies on the injection of chemicals to boost oil recovery. In this overview, an up-to-date synopsis of chemical EOR with detailed explanation of the chemicals used, and the mechanism governing their oil recovery application have been discussed. Challenges encountered in the application of the various conventional chemical EOR methods were highlighted, and solutions to overcome the challenges were proffered. Besides, the recent trend of incorporating nanotechnology and their synergistic effects on conventional chemicals stability and efficiency for EOR were also explored and analysed. Finally, laboratory results and field projects were outlined. The review of experimental studies shows that porescale mechanisms of conventional chemical EOR is enhanced by incorporating nanotechnology, hence, resulted in higher efficiency. Moreover, the use of ionic liquid chemicals and novel alkaline-cosolvent-polymer technology shows good potentials. This overview presents an extensive information about chemical EOR applications for sustainable energy production.
\end{abstract}

Keywords Polymer $\cdot$ Surfactant $\cdot$ Foam $\cdot$ Nanofluid $\cdot$ Enhanced oil recovery $\cdot$ Nanotechnology

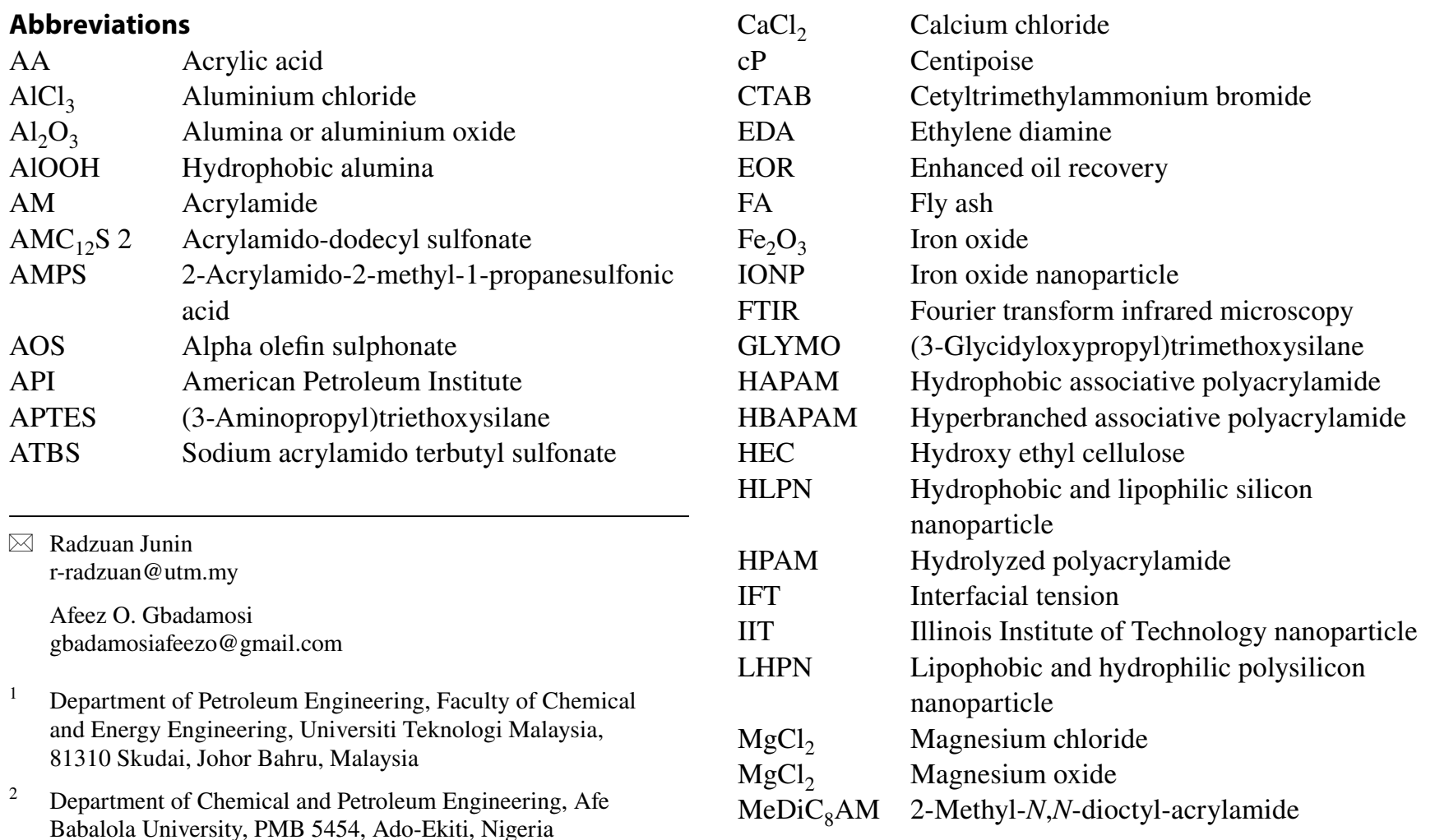




$\begin{array}{ll}\text { MWCNT } & \text { Multi-wall carbon nanotube } \\ \mathrm{NaCaS} & \text { Sodium caseinate } \\ \mathrm{NaCl} & \text { Sodium chloride } \\ \mathrm{NaHCO} & \text { Sodium hydrogen carbonate } \\ \mathrm{NP} & \text { Nanoparticle } \\ \mathrm{NWPN} & \text { Neutrally wet polysilicon nanoparticle } \\ \text { OOIP } & \text { Original oil in place } \\ \text { PAA } & \text { Polyacrylic acid } \\ \text { PA-S } & \text { Poly(AMPS) styrene } \\ \text { PAMAM } & \text { Polyamido amide } \\ \text { PAM } & \text { Polyacrylamide } \\ \text { PEG } & \text { Polyelectrolyte glycol } \\ \text { PECNP } & \text { Polyelectrolyte nanoparticle } \\ \text { PGN } & \text { Polymer grafted nanoparticle } \\ \text { PNS } & \text { Polymeric nanofluid suspension } \\ \text { PNRS } & \text { Petroza commercial surfactant } \\ \text { POEOMA } & \text { Poly(oligo(ethylene oxide) mono methyl } \\ & \text { ether methacrylate) } \\ \text { PSNP } & \text { Polysilicon nanoparticle } \\ \text { PG } & \text { Propyl gallate } \\ \text { PVA } & \text { Polyvinyl alcohol } \\ \text { PVP } & \text { Polyvinyl pyrrolidone } \\ \text { SiO } & \text { Silica or silicon oxide } \\ \text { SC } & \text { Sodium cumenesulfonate } \\ \text { SDS } & \text { Sodium dodecyl sulphate } \\ \text { TiO } & \text { Titanium oxide } \\ \text { TTFA } & \text { Thermally treated fly ash } \\ \text { TX-100 } & \text { Triton X 100 surfactant } \\ \text { WA } & \text { Wettability alteration } \\ \text { WF } & \text { Waterflooding } \\ & \\ & \end{array}$

\section{Introduction}

Oil and gas resources remain the world's major contributor to energy supply even with the recent energy generation from renewable sources $[1,2]$. As global energy demand increases in juxtaposition to dwindling energy resources, maximizing oil recovery from previously under-exploited reserves becomes crucial to meet the ever increasing energy demand [2]. The processes of oil recovery are majorly in three stages namely: primary, secondary and tertiary (EOR) stage. After the application of primary and secondary oil recovery techniques, two-third of the original oil in place (OOIP) remains in the reservoir [3, 4]. This is either because the oil is trapped by capillary forces (residual oil) or bypassed in some other way. The bypassed oil arises due to reservoir heterogeneities or because of unfavourable mobility ratio between the aqueous and oleic phase. On the other hand, the residual oil is made up of discrete ganglia that are produced when a finger-like protrusion of the oleic mass forms a narrow neck by the combined effects of local pressure gradient and interfacial tension (IFT) [5].
To enhance the overall oil displacement efficiency, numerous EOR methods have been devised and utilized [4, 6-9]. During oil recovery, the overall oil displacement efficiency is a combination of macroscopic (volumetric sweep) and microscopic (pore scale) displacement efficiency. Macroscopic displacement efficiency is a measure of the effectiveness of the injected fluids in contacting the oil zone volumetrically with respect to the total reservoir volume while microscopic displacement efficiency is the efficiency related to the ability of the displacing fluid(s) to mobilize oil trapped at the pore scale when it contacts the oil. Summarily, any mechanism that can increase oil recovery efficiency at either the micro or macro-scale or both is beneficial for EOR [10]. The devised and utilized EOR methods are majorly categorized into thermal and non-thermal EOR methods [11]. Unfortunately, thermal EOR methods are unsuitable for reservoirs with great depth and thin pay zone. Thus, nonthermal EOR has received prodigious attention for recovering oil bypassed or trapped in the reservoir [12].

Amongst all the EOR techniques, chemical EOR method, a non-thermal EOR method, has been adjudged as the most promising because of its higher efficiency, technical and economic feasibilities and reasonable capital cost [13]. The application of this EOR method became popular in the 1980s due to higher oil prices and technological advancement that enables understanding their mechanism. Chemical EOR methods increase oil recovery by increasing the effectiveness of water injected into the reservoir to displace the oil. Dependent on the type of chemical EOR process, chemicals injected with the water slug alter the fluid-fluid and/or fluid-rock interaction in the reservoir. This includes lowering of the IFT between the imbibing fluid and oil or an increment in the viscosity of the injectant for improving mobility and conformance control. Besides, the injected chemicals results in wettability alteration of the rock to increase oil permeability [14].

The well-known traditional chemical EOR methods are polymer flooding, surfactant and alkaline flooding [15]. However, the conventional chemical EOR methods have their limitations. Polymers, whose main recovery mechanism is to increase viscosity of injectants and consequently mobility, suffers viscosity loss in the presence of reservoir brines and elevated temperature conditions. Surfactant and alkali lose their efficiency during their flow in porous media due to adsorption phenomena. Subsequently, different modes of chemical flood injections were devised, studied and applied for EOR processes. These include the binary mix of alkali-surfactant (AS), surfactant/polymer (SP), alkaline/polymer (AP), and alkaline/surfactant/polymer (ASP) slug (see Fig. 1). The synergy of the combined conventional chemicals recorded an improved efficiency during their applications in oil wells. Recently, the use of foam enhanced by surfactants and polymers, for improved stability 


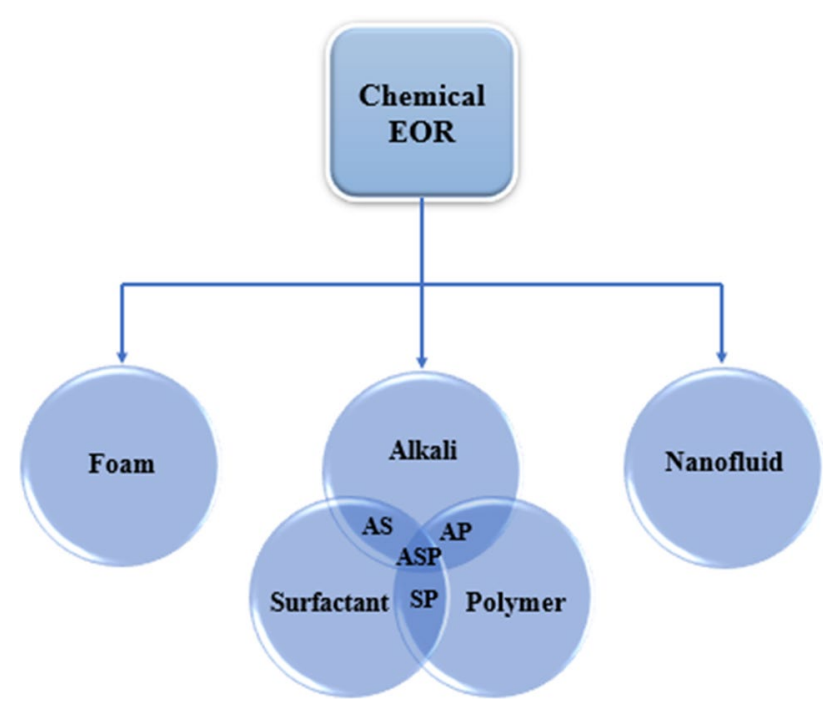

Fig. 1 Classification of EOR technologies

and mobility control have been studied and found to improve oil recovery [16-19].

More recently, the evolution of nanotechnology and their applications to improve the efficiency of various processes in the fields of metallurgy, electronics, medicine, aeronautics, catalysis, and fuel cells have prompted its use and application in the oil and gas industry [20-23]. The field of nanoscience and nanotechnology describes the creation and exploitation of materials with structural features having at least one of its dimensions in the nanometre range (1-100 nm). The "engineered nano-material" is called nanoparticle. The resultant improvement in the functional properties of a process generated due to addition of nanoparticles is attributable to their scalable and quantum effects. The application of this functional materials requires a base fluid such as gas, oil, water, or any other suitable liquid substance, hence, they are termed nanofluid. The application of nanotechnology has proffered solutions to various oil and gas problems ranging from drilling operations, petroleum exploration, inhibiting asphaltene depositions and gas hydrate formations, hydraulic fracturing jobs and EOR [24-27].

For EOR processes, nanofluid flooding has been evaluated and explored as a chemical EOR process with field application reported in Colombia [28]. The mechanism of the improved oil recovery were identified as structural disjoining pressure, wettability alteration, IFT reduction and improved viscosity of injectant [29]. More recently, the addition of nanoparticles to conventional EOR chemicals have been studied and reported to yield novel materials with excellent and fascinating properties. For example, polymeric nanofluids, a synergistic combination of nanoparticle and polymers were found to possess improved rheological properties and stability for application in the presence of high-temperature and high-salinity conditions [30]. Furthermore, the synergistic application of nanoparticles with surfactant lowers their adsorption via competitive adsorption mechanism, while their applications with foams generate stable foams with longer half-life [31].

This overview is a fundamental study that presents the current scenario of available research on chemical EOR. First, a survey of conventional chemical EOR method was carried out. The conventional EOR chemical types were identified and the mechanism of their EOR applications are discussed, and their limitations are highlighted. Thereafter, the binary application of conventional chemical EOR methods were also defined and analysed. Afterwards, the recent trend of incorporating nanotechnology for chemical EOR was also explored. The various nanofluid types, mechanism of their application and laboratory studies were outlined. Finally, the challenges associated with chemical EOR methods were enumerated and recommendations for future works were proffered.

\section{Conventional chemical EOR methods}

The notable conventional EOR chemicals are polymers, alkali, and surfactants. The injection of polymers with waterfloods increases the viscosity of the aqueous phase, and consequently mobility as they move from the injection well towards the producer. Additionally, the polymer solution increases oil recovery by reducing permeability to water in the reservoir [32]. Surfactant solutions reduce the IFT between water and crude oil by reacting with certain crude oil constituents, thereby, solubilizing interfacial films, and causing emulsification [33]. The IFT reduction causes lowering of the capillary forces of trapped and residual oil. Besides, surfactant adsorb on reservoir rocks to change rock wettability, hence, an increased oil recovery. Alkali flooding operates with a mechanism in similitude to surfactant solutions though with a different injectant [34]. Foam flooding ensures diversion of injected fluid from thief zones to low permeable regions of the reservoir [35]. Meanwhile, AP, AS, and ASP flooding are borne out of the basis to incorporate the different strengths and efficiency of alkali, surfactant and/or polymer solutions to improve the pore scale and sweep efficiency of the OOIP [36].

\section{Polymer flooding}

When waterflooding of an oil reservoir proves inadequate due to viscous fingering phenomena culminating in early water breakthrough, polymer flooding may be introduced/ incorporated. The process of polymer flooding involves the injection of high molecular weight water-soluble polymers along with the water slug to increase the viscosity of the 
injectant $[37,38]$. The incremental viscosity of the injectant improves the mobility and conformance control of the injected slug and eradicates viscous fingering phenomena. Consequently, early water breakthrough normally encountered in waterflooding process is suppressed and an incremental oil recovery factor is achieved. Polymer flooding has been successfully implemented in many oilfields either on a pilot scale or commercial scale for several decades. This includes the Daqing oilfield in China, East Bodo Reservoir and Pelican Lake field in Canada, Marmul field in Oman, and Tambaredjo field, Suriname, to mention just a few [39]. In addition, polymer flooding has maintained its increasing importance to the current energy market. The most notable contribution is the reported incremental oil production of up to $300,000 \mathrm{bbl} / \mathrm{day}$ from Daqing oil field in China [33].

\section{Mechanism of polymer flooding}

Polymer flooding improves oil recovery through a combined mechanism of mobility control, disproportionate permeability reduction and viscoelastic nature of the polymers.

Mobility control Mobility ratio is defined as the ratio of the mobility of the injectant (water) to the mobility of the displaced fluid (oil). Equation (1) depicts the mobility ratio of a waterflood as:

$M=K_{\mathrm{w}} \mu_{\mathrm{o}} / K_{\mathrm{o}} \mu_{\mathrm{w}}$,

where $M$ is the mobility ratio, $\mu_{\mathrm{o}}$ is oil viscosity $(\mathrm{cP}), \mu_{\mathrm{w}}$ is water viscosity $(\mathrm{cP}), K_{\mathrm{o}}$ is permeability to oil $(\mathrm{mD})$, and $K_{\mathrm{w}}$ is permeability to water $(\mathrm{mD})$. Mobility ratio dictates the stability of the oil displacement process.

If $M>1$, this is an indication that the water is more mobile than the oil. This depicts unfavourable condition as water fingers through the oil zone leading to an early breakthrough and a lower oil displacement efficiency (see Fig. 2a). To ensure a high macroscopic sweep efficiency, it is always required that $M \leq 1$. Figure $2 \mathrm{~b}$ illustrates the way polymer floods influences oil recovery through the reduction of mobility ratio. The presence of polymer in the displacing phase causes an increase in the viscosity of the injectant. Consequently, this results in a stable front of the displacing phase totally denuded of viscous fingers and/channels within the reservoir, thereby, resulting in a higher oil recovery [5, $16,40]$.

Disproportionate permeability reduction (DPR) In addition to the concept of mobility ratio, polymer floods improve sweep efficiency through disproportionate permeability reduction. Due to the heterogeneous nature of some reservoirs, they possess an uneven distribution of permeability (having a different permeability in different layers). This results in channelling of excessive water production through high permeability layers, leading to large amount of movable oil and gas remaining trapped in low permeability zones thereby causing poor recovery in primary and secondary stages of production [41]. During polymer flooding, the polymer solutions injected into the heterogeneous reservoir builds up flow resistance to water in the portions of the reservoir it penetrates, thus, lowering the water relative permeability $\left(K_{\mathrm{rw}}\right)$ while ensuring little or no reduction in the oil relative permeability $\left(K_{\mathrm{ro}}\right)$. This mechanism is termed disproportionate permeability reduction (DPR). The increased resistance of the polymer to water diverts subsequently injected water into unswept or poorly swept (low permeable) regions of the reservoir through segregation of flow pathways and layer formation on pore wall by the adsorbed polymer, thereby, resulting in a higher oil recovery [42].

Viscoelasticity of polymeric molecules Polymer viscoelasticity is the third mechanism posited to be responsible for improved macroscopic efficiency during polymer flooding. Unlike Newtonian fluids, polymers undergo a series of expansion and contraction (stretching and recoiling) during their flow in porous media [43]. This helps the polymeric
Fig. 2 Typical mobility ratio of a waterflooding process $(M>1.0)$, b polymer flooding process $(M \leq 1.0)$ [5]

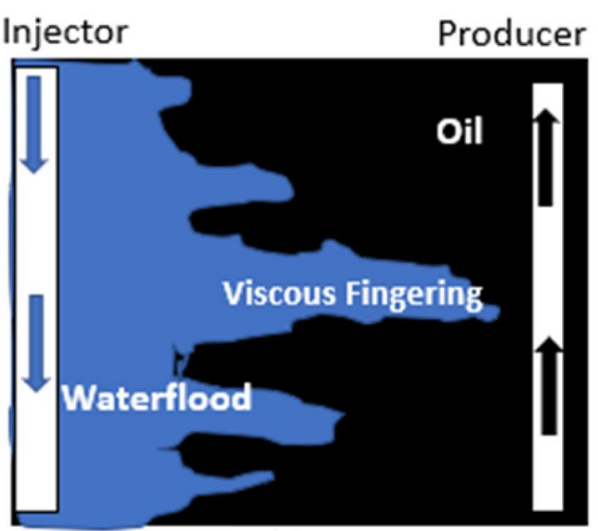

(a)

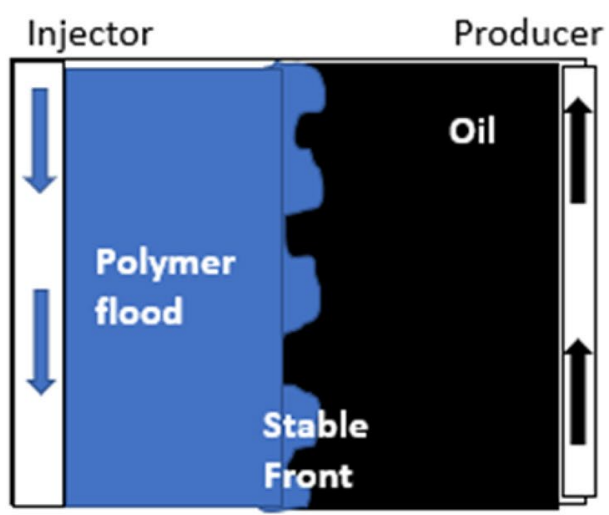

(b) 
molecules to generate additional "elastic viscosity" which improves macroscopic and microscopic displacement efficiency. Urbissinova et al. [44] and Veerabhadrappa [45] investigated the effect of viscoelastic properties of polymer on macroscopic sweep efficiency. The elastic difference of the polymer solution with the same shear viscosity was generated using polymer of similar average molecular weight but different molecular weight distribution (MWD). The result of their individual experiment indicated that high elastic polymer solution exhibited a considerably higher resistance to flow through porous media and stability of the propagating front thereby minimizing fingers. This cumulated in a higher sweep efficiency, lower residual oil saturation and an improved oil recovery.

\section{Types of EOR polymers}

Generally, two major classifications exist for polymers used during polymer flooding recovery operations, namely, synthetic polymers and biopolymers. Typical examples of synthetic polymers are polyacrylamides and it derivatives such as partially hydrolysed polyacrylamide (HPAM), hydrophobically associating polyacrylamide (HAPAM), and copolymers of acrylamide. On the other hand, biopolymers include xanthan gum, scleroglucan, hydroxyethylcellulose, carboxymethylcellulose, welan gum, guar gum, schizophyllan, mushroom polysaccharide, cellulose, and lignin (see Table 1). It is noteworthy that field application of HPAM and xanthan gum are the most widely reported and will be discussed further. For additional information of other polymer types, Taylor et al. [46] provided a comprehensive review of water-soluble of HAPAM, and Kamal et al. [47] described the state-of-the-art review of copolymers of acrylamide polymers for EOR. Additionally, $\mathrm{Pu}$ et al. [48] published a detailed review of polysaccharide biopolymer for EOR. Finally, Wever et al. [49] chronicled a general review of polymers for EOR.

Partially hydrolysed polyacrylamide (HPAM) Hydrolysed polyacrylamide (HPAM) is water-soluble, synthetic straightchain polymers used in EOR applications. It is a copolymer of polyacrylamide and polyacrylic acid obtained by the partial hydrolysis of PAM or by copolymerization of sodium acrylate with acrylamide [10]. They are widely regarded as the most used polymer for EOR [50]. HPAM is mostly preferred during field applications because it is resistant to bacterial attack, it has good water solubility, mobility control and it is a low-cost polymer [32, 48]. When used during polymer flooding, the polymer molecule undergo partial hydrolysis which converts some of the amide groups $\left(-\mathrm{CONH}_{2}\right)$ to carboxyl groups (-COO-), as illustrated in Fig. 3. Typical degree of hydrolysis $(\mathrm{DOH})$ for this polymer is $15-35 \%$ of the acrylamide (AM) monomers. Hence, they are negatively charged. The DOH accounts for many of the physical and rheological properties of the polymer solution such as adsorption, viscosity and water solubility. Nonetheless, HPAM is very sensitive to external factors such as $\mathrm{pH}$, temperature, salinity, shear forces and hardness. In reser-

Table 1 Merits and demerits of biopolymers

\begin{tabular}{|c|c|c|}
\hline Polymer type & Merits & Demerits \\
\hline Xanthan gum & $\begin{array}{l}\text { High resistance to salinity, temperature and shear } \\
\text { Possess long-term stability }\end{array}$ & $\begin{array}{l}\text { High susceptibility to biodegradation and oxidation } \\
\text { High risk of plugging of rock pores }\end{array}$ \\
\hline Carboxymethylcellulose & $\begin{array}{l}\text { The biopolymer is environmental friendly } \\
\text { It has good solubility in water }\end{array}$ & $\begin{array}{l}\text { It suffers from oxidative decomposition and thermal } \\
\text { degradation }\end{array}$ \\
\hline Schizophyllan & $\begin{array}{l}\text { Good resistance to temperature and salinity } \\
\text { High thickening efficiency } \\
\text { Low adsorption of its molecule on rock surface } \\
\text { It is a non-toxic material }\end{array}$ & Highly susceptible to biodegradation \\
\hline Hydroxyethylcellulose & $\begin{array}{l}\text { High solubility in water } \\
\text { Good tolerance to temperature and mechanical shearing } \\
\text { Excellent viscosifying effect }\end{array}$ & Biodegradation problem \\
\hline Welan gum & $\begin{array}{l}\text { Possess long-term stability } \\
\text { Excellent viscoelastic effect }\end{array}$ & $\begin{array}{l}\text { Performance dependent on inorganic cations present in } \\
\text { reservoir }\end{array}$ \\
\hline Scleroglucan & $\begin{array}{l}\text { Good resistance to shear and temperature effect } \\
\text { Excellent viscosifying effect }\end{array}$ & $\begin{array}{l}\text { High risk of biodegradation and oxidation } \\
\text { Poor filterability of the material in rock pores }\end{array}$ \\
\hline Guar gum & $\begin{array}{l}\text { It is an environmental friendly material } \\
\text { Excellent hydration properties and good compatibility to } \\
\text { salts over a wide range of } \mathrm{pH}\end{array}$ & $\begin{array}{l}\text { High risk of plugging in porous media } \\
\text { It suffers from poor thermal stability and weak elasticity }\end{array}$ \\
\hline Lignin & $\begin{array}{l}\text { It is an environmentally friendly material } \\
\text { Readily available at a low cost }\end{array}$ & $\begin{array}{l}\text { Insoluble in water } \\
\text { Biodegradation and oxidation effects }\end{array}$ \\
\hline Cellulose & Good resistance to temperature and mechanical shearing & Water-insolubility and heterogeneous swelling \\
\hline
\end{tabular}




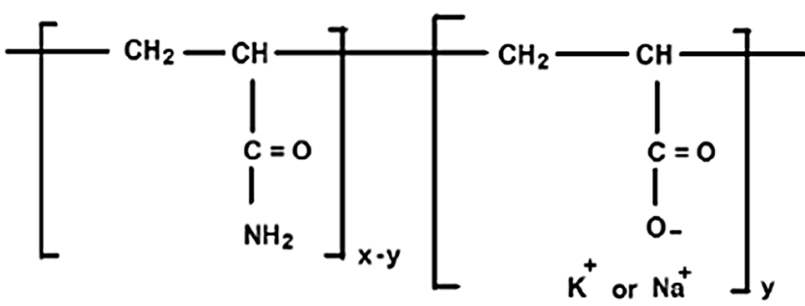

Fig. 3 Structure of partially hydrolysed polyacrylamide (HPAM)

voirs characterized by extreme conditions of this factors, HPAM molecule loses its viscosity enhancement property and consequently its efficiency $[47,51]$. Field applications of HPAM as polymer for EOR have been reported in literature $[47,52]$.

Xanthan gum Xanthan gum polymer is a polysaccharide obtained via fermentation of glucose and its isomer fructose by different bacteria. Xanthomonas campestris bacterium is widely regarded as the most efficient producer of xanthan gum [53]. Figure 4 depicts the chemical structure of xanthan gum displaying the presence of carbohydrates: glucose, mannose and glucuronic units. The biopolymer is characterized with rigid polysaccharide chains which make it resistant to degradation in the presence of salinity, temperature and shear forces [54]. The polymer is also regarded as a polyelectrolyte due to the presence of charged moieties (i.e., acetate and pyruvate groups) on the side chain of the biopolymer. Due to its high molecular weight which ranges from 2 to $50 \times 10^{6} \mathrm{~g} / \mathrm{mol}$, xanthan gum demonstrates high thickening capability required for mobility control in reservoirs $[10,49]$. Compared to synthetic acrylamide polymer such as HPAM, xanthan gum has a more rigid structure. Modelling the rheological behaviour of xanthan gum with available theoretical model (such as Herschel-Bulkley and Ostwald's models) shows the polymer exhibits shear thinning behaviour which corresponds with an appropriate injectivity for field operations [48].

Relative to HPAM, xanthan gum is less sensitive to mechanical shear, elevated salinity and/or divalent ion concentration, and displays good resistance to high temperatures. For a given temperature, the viscosity of xanthan solution display resistance to increasing temperature conditions when the ionic strength is high. This is because xanthan gum undergoes a cooperative conformational transition from a disordered conformation to a more rigid and ordered structure upon the addition of salt, hence, their improved stability [55]. Conversely, the viscosity of xanthan solution decreases strongly with increasing temperature at low ionic strength $[48,49,55]$. The major drawback of the application of this polymer for numerous field operations is the potential plugging risk caused by the cell debris and bacterial sensitivity. Researchers have shown that salt-tolerant aerobic and anaerobic microorganisms degrade xanthan gum resulting in high loss of its solution viscosity [48]. Albeit, biocides such as formaldehyde can be used to suppress the growth of xanthan gum degrading microorganisms, however, their use render the environmental impact of the polymer obsolete and make the overall polymer flooding process expensive. Field application of xanthan gum flooding was reported in ShengLi Gudong oilfield in China where successful pilot test was conducted and field trials were implemented with a favourable response to water cut and oil production rate.

\section{Challenges of polymer flooding}

The main objective of the addition of polymers to displacement fluids is to viscosify the injected brine. However, significant interactions such as electrostatic interactions and London dispersion forces occur between the transported polymer molecules and rock surface in the reservoir [5]. These causes retention of polymer molecules and results to the formation of a bank of injection fluid wholly or partially
Fig. 4 Structure of xanthan gum biopolymer [54]

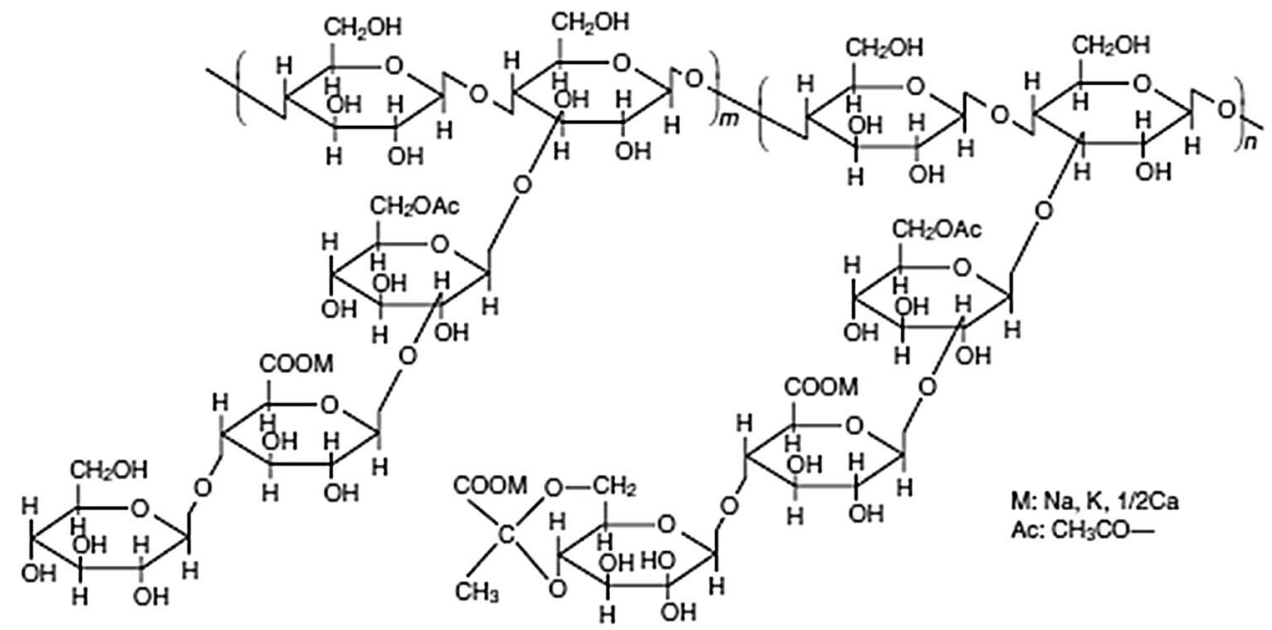


denuded of polymer depending on the degree of retention of the transported polymer molecules. Hence, the final viscosity of the injectant in the reservoir is lower than the target viscosity required, thus, resulting in a reduction of the effectiveness and efficiency of the polymer flood [56]. Factors that influence the retention of polymers in porous medium include polymer type and concentration, molecular weight, rock permeability, flow rate, salinity, temperature and the presence of clay minerals. Overall, polymer retention is an important factor that governs the economic viability of a polymer flooding process as they have an impact on the rock permeability, the viscosity of the injected polymer solution, and consequently the oil recovery process. The three main polymer retention mechanisms in porous media are hydrodynamic retention, mechanical entrapment and polymer adsorption. Figure 5 illustrates the polymer retention mechanisms. Further details of these mechanisms have been reviewed in our previous article [57].

\section{Surfactant flooding}

Surfactant flooding is a proven EOR technique used for mobilizing residual oil trapped in the reservoir [58]. The aim of surfactant injection into reservoir for improving oil recovery factor is to alter the fluid/fluid interaction by reducing IFT between the oil and brine, and fluid/rock properties via wettability alteration of the porous medium. A surfactant, otherwise known as surface-active agent molecule is amphiphilic in nature. This means surfactants are characterized with two functional groups within their organic shell. These are the hydrophilic group which is usually water-soluble and hydrophobic or non-polar group which is often oil-soluble. The lipophilic hydrophobic group is usually a long-chain hydrocarbon, fluorocarbon, a siloxane chain, or a short-polymer chain, which may or may not be branched. On the other hand, the lipophobic hydrophilic group is formed by moieties with their classification depending on the inherent organic compound.

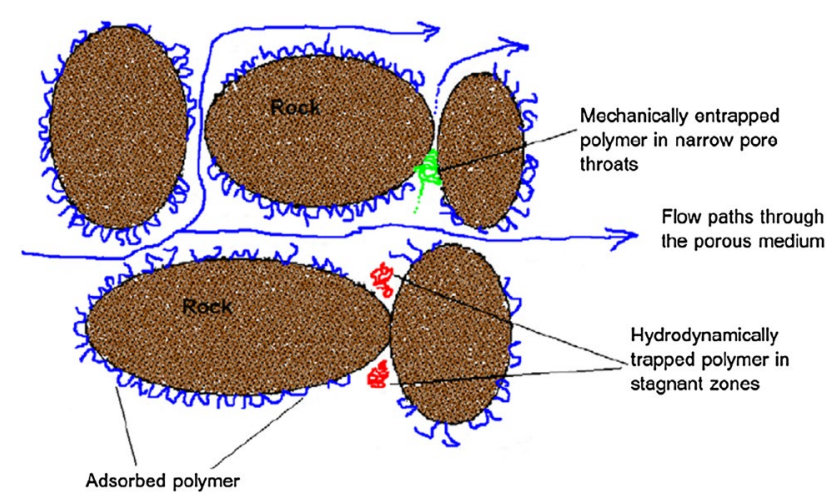

Fig. 5 Polymer retention mechanisms in porous medium [5]
The moieties include quaternary ammonium salts, carboxylates, alcohols, sulfonates, polyoxyethylenated chains and sulphates. Various laboratory and field applications of surfactants have been reported in literature [59].

\section{Mechanism of surfactant flooding}

Surfactant flooding improves pore-scale displacement efficiency through the mechanism of interfacial tension reduction, or wettability alteration, or a combination of both mechanisms.

Interfacial tension reduction During secondary recovery via waterflooding, it is practically impossible for water to displace all the oil in the pore scale due to trapping of oil by capillary forces. This capillary force is measured by a dimensionless capillary number $\left(N_{\mathrm{c}}\right)$ defined in Eq. (2) as:

$N_{\mathrm{c}}=\frac{\mu \cdot v}{\sigma \cdot \cos \theta}$,

where $\mu$ is the displacing fluid viscosity, $v$ is the displacing Darcy velocity, $\theta$ is the contact angle, and $\sigma$ is the IFT between the displacing fluid (water) and the displaced fluid (oil).

$N_{\mathrm{c}}$ is closely related to residual oil saturation and oil recovery and increases as residual oil saturation decreases. Consequently, a higher $N_{\mathrm{c}}$ will result in a higher oil recovery. A typical brine flooding has a $N_{\mathrm{c}}$ in the range of $10^{-7}$ to $10^{-6}$. Increasing $N_{\mathrm{c}}$ from this value to a range of $10^{-2}$ reduces the residual oil saturation to the barest minimum and result in an increase of the oil recovery factor. From Eq. (2), this can be achieved in three ways: (1) increasing the displacing fluid viscosity $(\mu) ;(2)$ increasing the injection fluid velocity $(v)$; (3) reducing the IFT $(\sigma)$. Increasing the injection fluid velocity may cause the injection pressure to be greater than the fracture pressure of the reservoir, thereby, fracturing the reservoir rock. Meanwhile, increasing the displacing fluid viscosity using polymer solutions increases the capillary number by less than 100 times [42]. Practically, only the method of reducing IFT can be used to increase $N_{\mathrm{c}}$ by 1000 times. This is achieved with the aid of surfactants.

When surfactant solutions are injected along with brine into oil reservoirs, the hydrophilic head reacts with water while the hydrophobic tail interacts with the components of the crude oil. As illustrated in Fig. 6, an adsorbed film occurs as a result of the interaction between the oil and alkyl tail of the surfactant, hence, lowering the IFT at the oil/water interface. Reduction of IFT at the oil/water interface weakens the capillary forces withholding the trapped oil, thereby, causing oil droplets to flow with ease from the pore throats of the rock to form an oil bank downstream. 


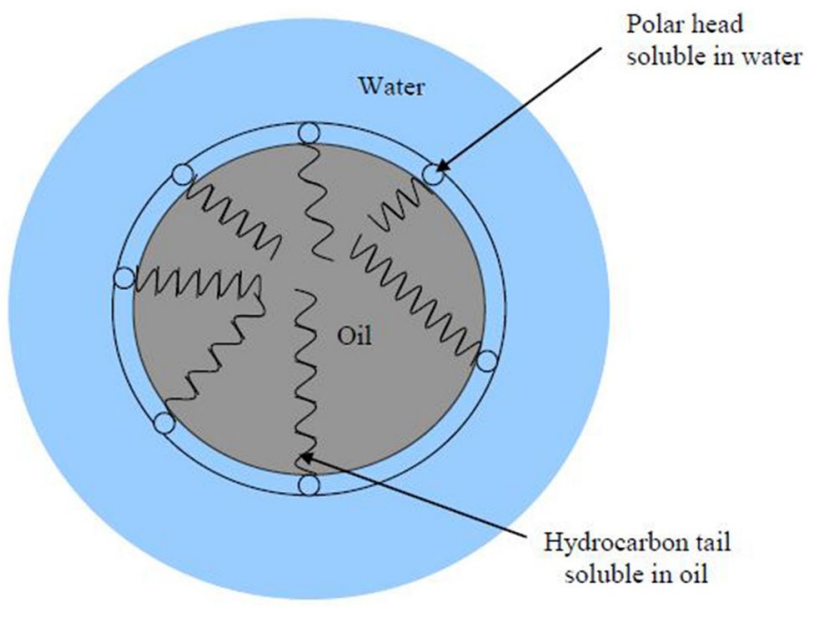

Fig. 6 Adsorption of surfactant at oil/water interface [10]

Wettability alteration The propensity or inclination of a solid surface for a particular type of fluid in the presence of other immiscible fluids is termed wettability $[60,61]$. In a reservoir rock system, the wettability of the rock surface dictates and controls the location, distribution and flow of fluids within the particular reservoir [62]. This petrophysical property is of particular importance because it influences oil recovery parameters such as capillary pressure and relative permeability. The wettability of most oil reservoirs is categorized into oil-wet, water-wet and mixed wet state [63]. This property of reservoir rock system can be measured by either of the following methods: surface imaging test, zeta potential measurements, spontaneous imbibition and contact angle measurements. Most studies of wettability alteration measurements are carried out using contact angle, which is defined by the point where the interface of the oil and water meets at the rock surface. Surface with contact angle $\theta>90^{\circ}$ is considered oil-wet while $\theta<90^{\circ}$ is considered water-wet. Altering the wettability of a surface from oil-wet to water-wet diminishes the adhesive force of capillarity and increase the oil permeability of the reservoir, as depicted in Fig. 7. Thus, it can be deduced that oil recovery is more easily achieved in water-wet compared to oil-wet reservoir.

The use of surfactant for wettability alteration has been exclusively studied for both conventional and unconventional reservoir rock system $[59,61,64]$. For unconventional (shale and tight) reservoirs characterized by low and/or ultra-low permeability, addition of surfactants at appropriate concentration into frac fluids were reported to improve the performance of hydraulic fracture treatment by altering the matrix wettability, and consequently the fluid flow behaviour [65, 66]. Accordingly, spontaneous imbibition occurs, hence, the aqueous phase penetrates into the matrix by overcoming the capillary forces trapping the oil in place, thereby, resulting in a higher oil recovery. Similarly, surfactants are used as active agents to recover oil from conventional sandstone and carbonate reservoirs [67-69]. The mechanism of wettability alteration of conventional rock pores by surfactant is termed a cleaning mechanism whereby the surfactant desorbs the oil-wet layer. Desorption of the oil-wet layer by surfactant alters the wettability of the surface and changes it to a more water-wet state.

Carbonate reservoirs are preferentially treated with cationic surfactants while sandstone reservoirs are treated with anionic surfactants because of the likeness of their charge which makes them more efficient for the respective reservoir rock system [70]. In carbonate reservoirs, the negatively charged organic components of crude oil adsorb on the positively charged mineral surfaces of the rock pores. When cationic surfactants are added, ion-pair formation interactions occur between the monomer of the surfactant and anionic components of oil (mostly carboxylate) adsorbed on the rock surfaces from the crude oil $[67,71]$. Thereafter, adsorbed material at the rock surface is desorbed from the rock. Subsequently, water imbibition occurs and oil is ejected out of the core material [72]. Desorption of the oleic phase from the surface of the rock changes the wettability of the rock to water-wet $[71,73]$. Thus, more oil can be expelled, as illustrated in Fig. 8a.

On the contrary, anionic surfactants are unable to desorb the carboxylate group inherent in the oleic phase from the pore surface due to the likeness/similarity of their
Fig. 7 Improved permeability due to wettability alteration of rock from oil-wet to water-wet. Adapted from [125]

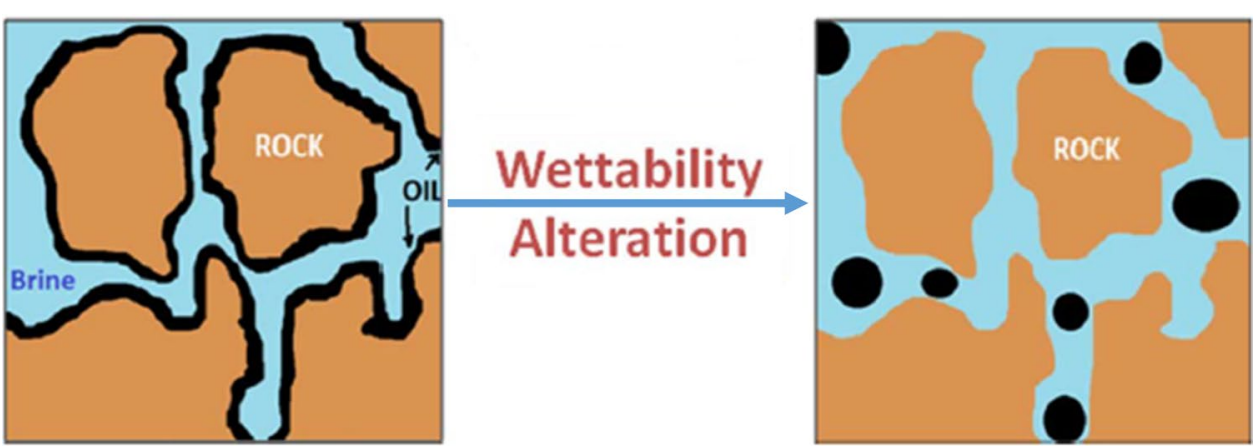




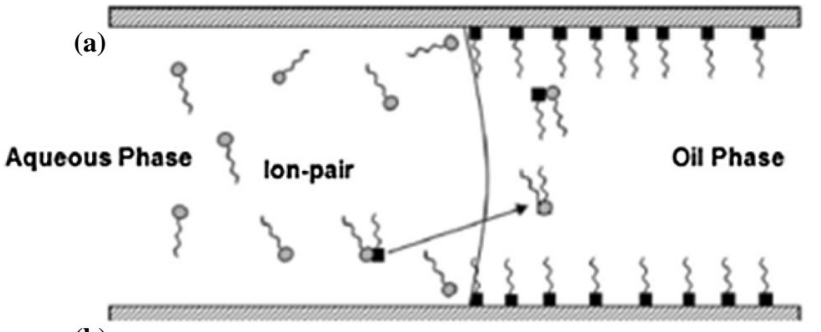

(b)

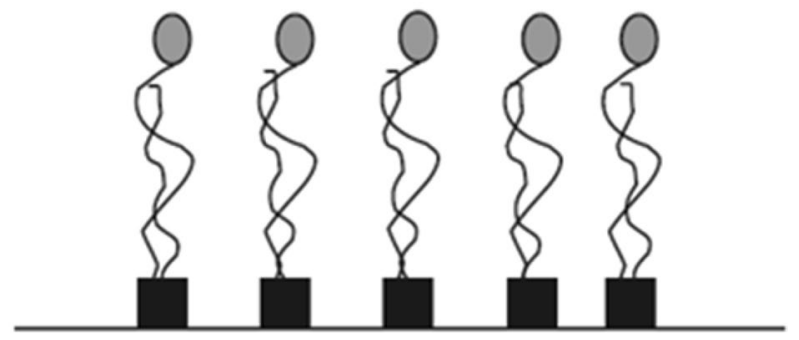

Fig. 8 Wettability alteration by a cationic surfactant [68], b anionic surfactant [74]

surface charges. Instead, they induce and create weak capillary forces through hydrophobic interaction between the hydrophobic tail of the surfactants and the oleic phase (see Fig. 8b) [74]. Albeit, the interaction also displaces the oil, it is not as efficient as the ion-pair interaction and changes oil-wet to neutral wet condition. Meanwhile, nonionic surfactants adsorb on rock surfaces by polarization of $\pi$ electrons and ion exchange [67]. Overall, cationic surfactants are more efficient wettability agents compared to other surfactant types. The mechanism of wettability alteration by surfactants of oil-wet carbonate surface is deemed suitable for explaining wettability alteration of oil-wet sandstone surfaces containing clay minerals where oil is adsorbed on the negatively charged sandstone surface by polar interactions, surface precipitation and acid/base interactions [75].

\section{Surfactant types and their structure}

Laboratory testing and field studies of surfactant EOR have appraised and assessed numerous surfactants for their suitability in oil recovery. They are majorly classified into anionic surfactants, non-ionic surfactants, cationic surfactants and zwitterionic surfactants (see Fig. 9) depending on the nature of the hydrophilic head group. Table 2 depicts the structures of these classes of surfactants. More recently, due to the deficiency of conventional surfactants in flooding operations, new sets of surfactants are being developed and tested for EOR applications. This includes polymeric surfactants, viscoelastic surfactants, Gemini surfactants, and biosurfactants. More details of the properties and efficiency

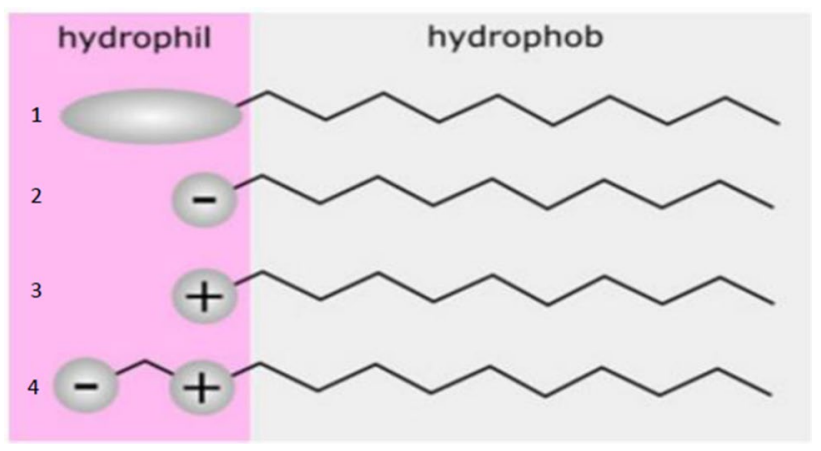

Fig. 9 Structure of the different class of surfactants

of this new class of surfactants have been reviewed by Raffa et al. [32], Kamal et al. [9], and Pal et al. [76].

Anionic surfactant Anionic surfactants are the most commonly used surfactants. This is largely due to the fact that most of the EOR works of surfactant flooding have focussed on sandstone reservoirs. The surface-active portion of this class of surfactant bears a negative charge such as carboxylate $\left(\mathrm{COO}^{-}\right)$, sulphate $\left(\mathrm{SO}_{4}^{2-}\right)$, or sulphonate $\left(\mathrm{SO}_{3}^{-}\right)$, though in association with a cation usually an alkaline metal $\left(\mathrm{Na}^{+}\right.$or $\left.\mathrm{K}^{+}\right)$. The sulphonate class of anionic surfactants is stable in higher temperatures, but susceptible to high salinity and precipitates in the presence of divalent cations. On the other hand, the sulphate class has greater tolerance salinity (both monovalent and divalent cations), but decompose at high temperatures [76].

Cationic surfactant Cationic surfactants are surfactants whose hydrophilic head bears a positive charge, though in conjunction with a halide group. They dissociate in water to form an amphiphilic cation and an anion. This class of surfactants is easily attracted to negatively charged surfaces of clays and is very efficient in altering reservoir rock wettability. Cationic surfactants have been identified to hold the key for unlocking the vast and abundant hydrocarbons trapped in carbonate reservoirs due to similitude of their surface charges. Nonetheless, they are more expensive than anionic surfactants because of the highpressure hydrogenation reaction required during their synthesis [77].

Non-ionic surfactant Unlike cationic and anionic surfactants, non-ionic surfactants do not ionize in aqueous solution. The hydrophilic group consists of non-dissociable functional groups such as alcohol, phenol, ether, ester, or amide. Meanwhile, the lipophilic group consists of the alkyl or alkylbenzene group. Although the hydrophilic group lacks ionic charge, they are soluble in water because of their inherent polarity caused by the presence of hydrogen bond 
Table 2 Surfactant types and classification [10, 59]

\begin{tabular}{|c|c|c|}
\hline Surfactant type & Examples & Structures \\
\hline \multirow[t]{12}{*}{ Anionic } & Sodium dodecylbenzene sulfonate & $\mathrm{CH}_{3}\left(\mathrm{CH}_{2}\right)_{11} \mathrm{C}_{6} \mathrm{H}_{4} \mathrm{SO}_{3}^{-\mathrm{Na}^{+}}$ \\
\hline & Sodium dodecyl sulphate (SDS) & $\mathrm{CH}_{3}\left(\mathrm{CH}_{2}\right)_{11 \mathrm{SO}_{1}^{-} \mathrm{Na}^{+}}$ \\
\hline & Sodium stearate & $\mathrm{CH}_{3}\left(\mathrm{CH}_{2}\right)_{16} \mathrm{COO}^{-} \mathrm{Na}^{+}$ \\
\hline & $N$-Ethoxy sulfonate & $\mathrm{H}\left(\mathrm{OCH}_{2} \mathrm{CH}_{2}\right)_{n}-\mathrm{O}-\mathrm{SO}_{2}-\mathrm{R}$ \\
\hline & Alcohol propoxy sulphate (APS) & $\begin{array}{l}\mathrm{ROH}-\left[\mathrm{CH}_{2}-\mathrm{CHO}-\mathrm{CH}_{3}\right]_{x}-\mathrm{SO}_{3}^{-} \mathrm{Na}^{+} \\
R=16-17, x=7\end{array}$ \\
\hline & Alpha-Olefin sulfonate (AOS) & $\begin{array}{l}\mathrm{R}-\mathrm{CH}=\mathrm{CH}-\left(\mathrm{CH}_{2}\right)_{n}-\mathrm{SO}_{3} \mathrm{Na} \\
R=\mathrm{C}_{10}-\mathrm{C}_{20} \\
n=10-20\end{array}$ \\
\hline & $\begin{array}{l}\text { Alkyl polyalkoxy alkyl sulfonate or alkyl aryl polyalkoxy } \\
\text { alkyl sulfonate }\end{array}$ & $\begin{array}{l}R \mathrm{O}\left(R^{\prime} \mathrm{O}\right)_{n} R^{\prime \prime} \mathrm{SO}_{3}^{-} \mathrm{M}^{+} \\
R=\mathrm{C}_{8}-\mathrm{C}_{24} \\
R^{\prime}=\text { ethyl or a mixture of ethyl and propyl } \\
R^{\prime \prime}=\text { Ethyl, propyl, hydroxypropyl, or butyl } \\
n=\text { integer from } 1 \text { to } 20, \text { preferably from } 2 \text { to } 8 \\
\mathrm{M}^{+}=\text {monovalent cation such as } \mathrm{NH}^{+}, \mathrm{Na}^{+}, \mathrm{K}^{+}\end{array}$ \\
\hline & Branched alkyl benzene sulfonate & \\
\hline & Docusate sodium & $\mathrm{C}_{20} \mathrm{H}_{37} \mathrm{NaO}_{7} \mathrm{~S}$ \\
\hline & Guerbet alkoxy sulphate & $\begin{array}{l}\mathrm{C}_{n} \mathrm{H}_{2 n+1} \mathrm{O}-\mathrm{PO}_{x}-\mathrm{EO}_{y}-\mathrm{SO}_{3}^{\mathrm{o}-} \\
n=\text { is an integer between } 12 \text { and } 44 \\
x=\text { is an integer between } 0 \text { and } 50 \\
y=\text { is an integer between } 0 \text { and } 100\end{array}$ \\
\hline & Sulfonated, ethoxylated alcohol or alkyl phenol & $\begin{array}{l}\mathrm{RO}\left(\mathrm{CH}_{2}\right)\left(\mathrm{CH}_{2}\right)_{x} \mathrm{CH}_{2} \mathrm{CH}_{2} \mathrm{SO}_{3}^{-\mathrm{M}^{+}} \\
\mathrm{M}^{+}=\text {monovalent cation such as } \mathrm{NH}^{+}, \mathrm{Na}^{+} \text {, and } \mathrm{K}^{+}\end{array}$ \\
\hline & Alkyl alcohol propoxylated sulphate & $\begin{array}{l}\mathrm{R}-\left(\mathrm{OHCH}_{2} \mathrm{CH}_{2} \mathrm{CH}_{2}\right)_{n} \mathrm{O} \mathrm{SO}_{3}^{o-} \mathrm{M}^{+} \\
\mathrm{M}^{+}=\text {monovalent cation such as } \mathrm{NH}^{+}, \mathrm{Na}^{+} \text {, and } \mathrm{K}^{+}\end{array}$ \\
\hline \multirow[t]{6}{*}{ Nonionic } & Polyoxyethylene alcohol & $\mathrm{C}_{n} \mathrm{H}_{2 n+1}\left(\mathrm{OCH}_{2} \mathrm{CH}_{2}\right)_{m} \mathrm{OH}$, where $n=8-18 ; m=3-15$ \\
\hline & Alkylphenol ethoxylate & $\begin{array}{l}\mathrm{C}_{19} \mathrm{H}_{19} \mathrm{C}_{6} \mathrm{H}_{4}-\left(\mathrm{OCH}_{2} \mathrm{CH}_{2}\right)_{n} \mathrm{OH} \\
n=5-10\end{array}$ \\
\hline & NEODOL & $\begin{array}{l}\mathrm{RO}\left(\mathrm{CH}_{2} \mathrm{CH}_{2} \mathrm{O}\right)_{x} \mathrm{CH}_{2} \mathrm{COO}^{-} \mathrm{M}^{+} \\
R=\mathrm{C}_{8}-\mathrm{C}_{18} \\
x=1-15 \\
M=\text { alkali or alkaline earth metal }\end{array}$ \\
\hline & NEODOL ethoxylate 91-8 & $\begin{array}{l}\mathrm{RO}-\left(\mathrm{CH}_{2} \mathrm{CH}_{2} \mathrm{O}\right)_{n}-\mathrm{H} \\
R=\text { blend of } \mathrm{C} 9, \mathrm{C} 10, \text { and } \mathrm{C} 11 \text { alcohol } \\
n=\text { integer from } 1 \text { to } 20, \text { an average number of } 8\end{array}$ \\
\hline & NEODOL 67 propoxylated sulphate (N67-7POS) & $\begin{array}{l}\mathrm{RO}-\left(\mathrm{OHCH}_{2} \mathrm{CH}_{2} \mathrm{CH}_{2}\right)_{n}-\mathrm{O}-\mathrm{SO}_{3}^{\mathrm{o}-} \mathrm{M}^{+} \text {, where } R=\text { blend } \\
\text { of } \mathrm{C} 16 \text { and } \mathrm{C} 17 \text { alcohols } \\
n=\text { integer from } 1 \text { to } 20 \text { with an average number of } 7\end{array}$ \\
\hline & Synperonic PE/F68 & $\begin{array}{l}\mathrm{HO}-\left(\mathrm{C}_{2} \mathrm{H}_{4} \mathrm{O}\right)_{m}-\left(\mathrm{C}_{3} \mathrm{H}_{6} \mathrm{O}\right)_{n}-\mathrm{H} \text {, where } n=\text { integer from } 1 \\
\text { to } 20 \text { and preferably } 2 \text { to } 8 \\
\mathrm{M}^{+}=\text {monovalent cation such as } \mathrm{NH}^{+}, \mathrm{Na}^{+} \text {, and } \mathrm{K}^{+}\end{array}$ \\
\hline \multirow[t]{3}{*}{ Cationic } & Cetyl trimethyl ammonium bromide (CTAB) & $\mathrm{CH}_{3}\left(\mathrm{CH}_{2}\right)_{15} \mathrm{~N}^{+}\left(\mathrm{CH}_{3}\right)_{3} \mathrm{Br}^{-}$ \\
\hline & Laurylamine hydrochloride & $\mathrm{CH}_{3}\left(\mathrm{CH}_{2}\right)_{11} \mathrm{NH}_{3}^{+} \mathrm{Cl}^{-}$ \\
\hline & Dodecyl trimethyl ammonium bromide (DTAB) & $\mathrm{C}_{12} \mathrm{H}_{25} \mathrm{~N}^{+}\left(\mathrm{CH}_{3}\right)_{3} \mathrm{Br}^{-}$ \\
\hline \multirow[t]{3}{*}{ Zwitterionic } & Dodecyl betaine & $\mathrm{C}_{12} \mathrm{H}_{25} \mathrm{~N}^{+}\left(\mathrm{CH}_{3}\right)_{2} \mathrm{CH}_{2} \mathrm{COO}^{-}$ \\
\hline & Lauramidopropyl betaine & $\mathrm{C}_{11} \mathrm{H}_{25} \mathrm{CONH}\left(\mathrm{CH}_{2}\right)_{3} \mathrm{~N}^{+}\left(\mathrm{CH}_{3}\right)_{2} \mathrm{CH}_{2} \mathrm{COO}^{-}$ \\
\hline & Cocoamido-2-hydroxypropyl sulfo betaine & $\mathrm{C}_{n} \mathrm{H}_{2 n+1} \mathrm{CONH}\left(\mathrm{CH}_{2}\right)_{3} \mathrm{~N}^{+}\left(\mathrm{CH}_{3}\right)_{2} \mathrm{CH}_{2} \mathrm{CH}(\mathrm{OH}) \mathrm{CH}_{2} \mathrm{SO}_{3}^{-}$ \\
\hline
\end{tabular}


and van der Waals interaction. As compared to ionic surfactants, non-ionic surfactants have a higher salinity tolerance, but a lower IFT reduction ability [78].

Zwitterionic surfactant Zwitterionic surfactants are characterized by the presence of anionic and cationic surface charges on their hydrophilic head. They exhibit both anionic and cationic properties upon dissociation. Besides, they possess good tolerance to high salinity and temperature conditions. Typical examples of this class of surfactants are the betaine and sulfo betaine [79].

\section{Challenges of surfactant flooding}

Like polymers, the major challenge of surfactant flooding process is surfactant retention. Surfactant retention may be due to phase trapping, precipitation or adsorption. The dominant surfactant retention mechanism is the surfactant adsorption process. Surfactant adsorption on rock pores results in loss and decrease in surfactant concentration, thereby, reducing the quantity of surfactant molecules available for the IFT reduction of oil-water interface, and consequently reduces the economic feasibility of the EOR method [80]. The adsorption process occurs when the interface is energetically favoured by the surfactant in comparison to the bulk phase. Thus, the adsorption at the solid-liquid interface takes place by the transfer of the molecule of the surfactant to the solid-liquid interface from the bulk solution phase [81]. The interaction of the chemicals and rock surfaces by electrostatic interaction, van der Waals interaction, chemical and lateral interaction, hydrogen bonding, hydrophobic bonding and solvation of various species resulting in polarization of $\pi$ electrons are responsible for surfactant adsorption on rock pores.

Surfactant adsorption is higher when opposite charges exist between the surfactant molecules and rock surfaces. Hence, it can be deduced that surfactant adsorption in reservoir is dependent on the nature of surfactant itself (i.e., its chemical structure) and the nature of the rock surface. Additionally, electrolyte concentration (salinity), temperature, $\mathrm{pH}$, composition of reservoir fluids and the condition of solution are other factors that dictate surfactant adsorption process in reservoirs rocks.

High-salinity conditions are found to result in high surfactant adsorption irrespective of surfactant concentration [82]. Contrariwise, surfactant adsorption is decreased with an increase in temperature due to the onset of higher kinetic energy. Meanwhile, the amount of surfactant adsorption at different $\mathrm{pH}$ depends on its resultant charge which will react with charges available at the surface. For instance, increasing the $\mathrm{pH}$ of a sandstone surface leads to the surface being negatively charged, and would lead to a reduction of anionic surfactant. Meanwhile, adsorption of anionic surfactant will increase if the $\mathrm{pH}$ is lowered. To prevent the chemical adsorption at the solid-liquid interface, it is important to bind the chemical molecules of the surfactant at the liquid-liquid or liquid-air interface. To this end, studies have suggested surfactant screening and selection by surface charge to be matched to specific reservoir rock as a means of reducing surfactant adsorption in reservoirs. More recently, the use of low-cost sacrificial agent (such as polyelectrolytes and ionic liquids) evolved, has been prodigiously researched, and is being exploited for reducing surfactant adsorption in reservoirs $[8,83]$.

\section{Alkali flooding}

Alkali flooding is an EOR technique that utilizes an alkali (a basic compound, ionic salt of an alkali metal or alkaline earth metal) to improve oil recovery factor. The method is distinct from other EOR methods on the basis that the chemicals that aid the oil recovery are generated in situ during the EOR process by saponification reaction [84]. Saponification reaction is defined as the reaction between an organic acid and caustic alkali to form soap indicated by the reaction in Eq. (3). Figure 10 illustrates the chemical model for the alkali-oil chemistry in reservoir rock. The organic acid is obtained from the acidic component of the crude oil. The generated soap acts as an in situ surfactant to lower IFT and emulsify the crude oil, thereby, improving oil recovery [85].

$\mathrm{HA}+\mathrm{OH}^{-} \leftrightarrow \mathrm{A}^{-}+\mathrm{H}_{2} \mathrm{O}$.

Along with the aforementioned low IFT and emulsification processes, different mechanisms have been postulated to be responsible for higher oil recovery by alkali flooding. Other mechanisms posited for EOR by alkali flooding

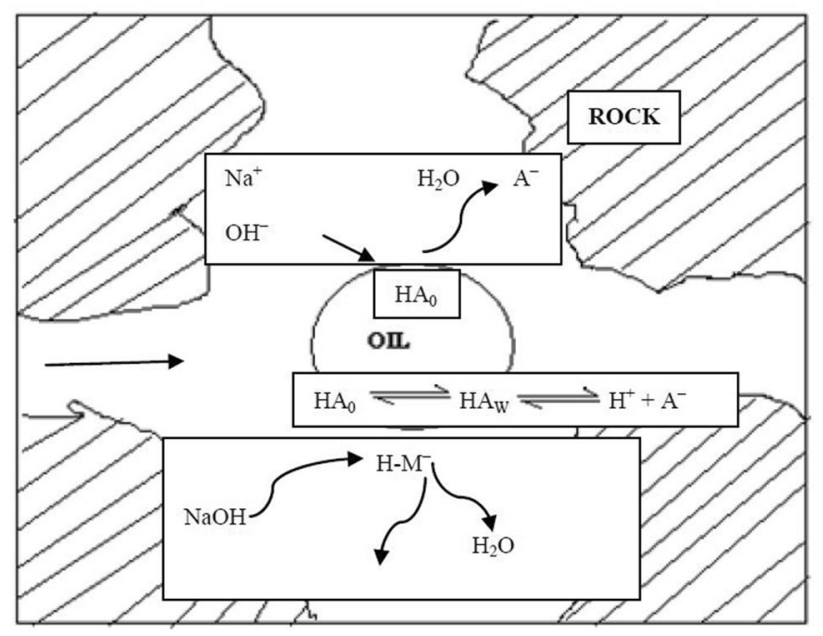

Fig. 10 Schematic of alkali flooding [36] 
includes: oil-phase swelling, wettability alteration, and disruption of rigid films [86]. The existence of divergent mechanisms is due to the dissimilar chemical character of the crude oil and the reservoir rock under distinct environments such as temperature, salinity, $\mathrm{pH}$, and hardness concentration. The different crude oil in different reservoirs exhibit widely disparate behaviours when they come in contact with alkali. Depending on the mineralogy of the rock, the alkali interacts with the rock in numerous ways such as surface exchange and hydrolysis, congruent and incongruent dissolution reactions, and insoluble salt formation by reaction with hardness ions in the fluid and those exchanges from rock surface.

Several alkalis have been screened for application in alkali flooding. These include sodium metaborate $\left(\mathrm{NaBO}_{2}\right)$, sodium carbonate $\left(\mathrm{Na}_{2} \mathrm{CO}_{3}\right)$, sodium hydroxide $(\mathrm{NaOH})$, and sodium bicarbonate $\left(\mathrm{NaHCO}_{3}\right)$. The selection of alkali to be used is dependent on the type of formation, clay and mineral content, and the presence of divalent cations. $\mathrm{NaOH}$ are less preferred because at elevated temperature, they interact strongly with the sandstone surface, thus, causing increased porosity and consequently sandstone weight loss. Moreover, caustic consumption resulting from the dissolution of the caustic alkali in silicate minerals pose detrimental factor during field application [87]. $\mathrm{Na}_{2} \mathrm{CO}_{3}$ is the most preferred alkali due to its low-cost and better transport properties in porous media. Nonetheless, the presence of calcium and other divalent cations cause precipitation of alkalis such as $\mathrm{Na}_{2} \mathrm{CO}_{3}$ unless soft brine is used. $\mathrm{NaBO}_{2}$ have better tolerance for divalent ions and have been suggested as replacement for $\mathrm{Na}_{2} \mathrm{CO}_{3}$ [88]. Meanwhile, $\mathrm{NaHCO}_{3}$ is preferred in reservoirs containing clay minerals. Finally, due to precipitation of alkali in carbonate reservoirs due to the presence of anhydrite $\left(\mathrm{CaSO}_{4}\right)$ and gypsum $\left(\mathrm{CaSO}_{4} \cdot 2 \mathrm{H}_{2} \mathrm{O}\right)$, sandstone reservoirs are the preferred formation for alkali flooding.

\section{Foam flooding}

Due to the limitations of gas injection methods which includes viscous fingering and gravity override, foam, a dispersion of gas in liquid, such that the liquid phase is continuous and some part of the gas phase is made discontinuous by a thin liquid film called lamellae emerged as a promising solution for improving oil recovery efficiency [89]. Foam controls oil recovery by displaying two favourable mechanisms that are beneficial to the EOR process. Firstly, foams increase the apparent viscosity of the injectant, thereby, promoting a more favourable mobility ratio. Lastly, the bubbles of the foam expand in porous media, hence, exhibiting selective fluid diversion from thief zones to lower permeability regions or unswept zones in the reservoir [90]. This makes the foam flooding process more efficient than water flooding, gas injection and water-alternating-gas injection process. Hitherto, foams are classified as a gas injection method. Examples of traditional foam flooding methods include $\mathrm{CO}_{2}$ foams, nitrogen foams, and air foams. Latterly, chemicals such as surfactants, protein and polymers have been used to synthesize stable foams with longer half-life [19, 82].

\section{Challenges of foam flooding}

For effective foam applications in EOR, the foam used in the flooding operation for oil recovery is expected to remain stable and propagate in the reservoir in the presence of resident reservoir oil and brines, at the prevailing reservoir temperature and salinity conditions [35,91]. Generally, conventional foams generated using surface-active agents (e.g., surfactant) help to lower surface tension and improve foam stability by their adsorption at the gas-liquid interface of the foam [92]. Nonetheless, chemical foams depend on the constant regeneration of foam lamellae for successful propagation in porous media $[93,94]$. The major challenge associated with the use of surfactant-stabilized foam and polymer-enhanced foam is the stability of their lamellae especially in porous media as the foam contacts the resident reservoir brines and crude oil [95]. This is because their adsorption on the rock surfaces in the presence of electrolytes can be very high [96]. Hence, their foams are thermodynamically unstable, with high rate of coalescence and coarsening. The major mechanisms of foam lamellae destruction and ageing process are liquid drainage, coalescence, and coarsening [97, 98].

\section{Binary combination of conventional chemical EOR}

Recently, binary combination of chemicals evolved and has been tested on pilot and field scale to further improve oil recovery. This method of EOR developed from the need to exploit the synergy of the individual chemicals and to complement each other weakness during flooding process. The binary combination led to the formation of alkali-surfactant, alkali-polymer, surfactant-polymer, and alkali-surfactant-polymer flooding process.

\section{Alkali-surfactant (AS) flooding}

During AS flooding, slug of alkaline solution is first injected and followed by slug of surfactant. The efficiency of the process is higher than the individual alkaline or surfactant flooding process. As earlier stated, the alkali reacts with naphthenic contents of the crude oil to generate in situ soap. The addition of surfactant to the alkaline solution further reduces IFT and creates emulsions with higher interfacial 
resistance. Furthermore, the presence of alkaline decreases the adsorption of expensive surfactant chemicals on clay mineral contents (such as montmorillonite, kaolinite and illite) of the rock pores because the charges of the mineral surfaces becomes more negative. The lower adsorption of the surfactant increases the amount of surfactant available in the reservoir to recover residual and capillary trapped oil in rock pores, hence, a higher oil recovery [99].

\section{Alkali-polymer (AP) flooding}

The shortcoming of alkaline flooding is that it lacks the required mobility control required to push oil in the reservoir due to a lower mobility of the displacing phase to the displaced phase. Simultaneous injection of polymer slug with alkali improves mobility control of injectant and complement the efficiency of alkali flooding. Also, the presence of alkali lowers the adsorption of polymer on rock pores [100]. However, an optimum concentration of alkali and polymer required for formulation of AP slug must be determined. This is because the presence of high concentration of alkaline may cause hydrolysis of the polymer molecules and impair its viscosity. Jung et al. reported a $30 \%$ incremental recovery of heavy oil by AP flood [101].

\section{Surfactant-polymer (SP) flooding}

Depending on the ultimate aim of the flooding process, either chemical can be injected as the first slug during SP flooding. If the aim of the flooding process is to lower adsorption, polymer slugs are injected first as sacrificial agent and for conformance control. Conversely, polymer slug are injected behind surfactant slug when the aim of the flooding process is to avoid fingering of chase water in the surfactant slug. Whichever injection mode is adopted, there is strong tendency for high efficiency of the mixture of both chemicals at their interface due to diffusion and dispersion in the reservoir. Besides, inaccessible pore volume phenomenon may aid the mixing of the chemicals when polymer slug is injected behind the surfactant. The synergy of both chemicals leads to a higher oil recovery [102].

\section{Alkali-surfactant-polymer (ASP) flooding}

ASP flooding technique involves the injection of alkali, surfactant and polymer solutions to achieve EOR. Due to the integrated synergy of the individual component of the injected slug, this method is widely regarded as the most promising chemical EOR process [103]. The combined chemicals improve both pore scale and volumetric sweep efficiency. The first slug comprises of alkali and surfactant which mobilizes residual oil trapped in the pore spaces.

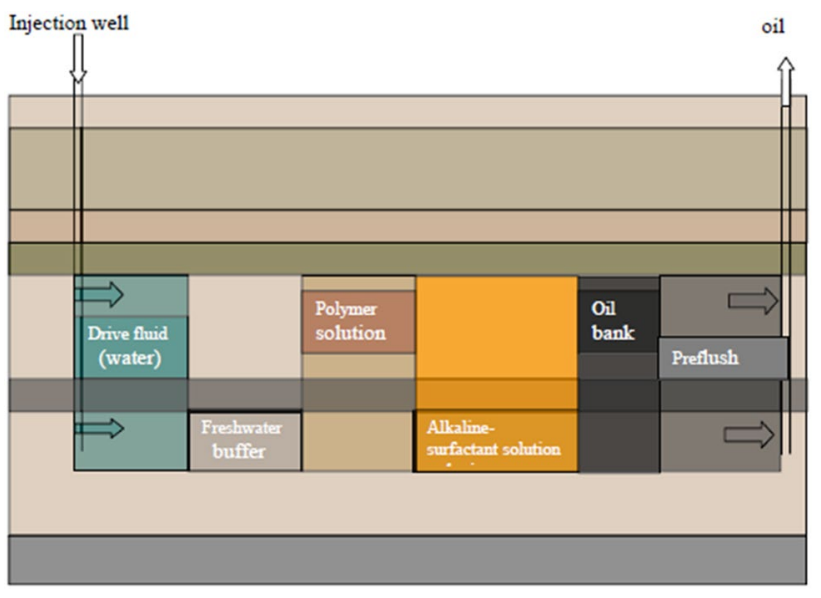

Fig. 11 Diagrammatic representation of ASP flooding [10]

Subsequently, polymer slug is injected to improve the mobility ratio and consequently the volumetric sweep efficiency [104]. Finally, a freshwater and drive water slug is injected to optimize the chemical recovery, as shown in Fig. 11.

The synergy of alkali and surfactant reduces IFT to ultralow values [102]. Besides, there is competition for adsorption of both chemicals on rock pores which ultimately results in lower adsorption of the surfactant. An additional mechanism of this EOR process is the synergy between the injected synthetic surfactant and the in situ generated soap caused by the presence of alkali $[100,105]$. The optimum salinity for the generated soap is very low. Due to this, the injected alkali is lower than the amount required for consumption and cannot be propagated in the reservoir. Meanwhile, the optimum salinity of surfactant is high. Thus, the addition of synthetic surfactant complement the deficiency of the alkali such that when the soap and the surfactant mixes, the optimum salinity range in which IFT reaches its low values is increased and widened [76, 99, 105]. Finally, the polymer content improves the mobility of the injected chemicals and aid a higher conformance control and sweep efficiency [104].

Like other EOR process, ASP flooding has its own challenges. This include surfactant precipitation and scaling issues, difficulty in treatment of produced emulsions and pitfall of produced water disposal to conform with set limit.

a. Surfactant precipitation and scaling issues Surfactant precipitation occurs as a result of the reaction between alkali and divalent metal cations present in formation brines. The precipitated material deposit scales on wellbore equipment, thereby, fouling it. For this reason, ASP is deemed unsuitable in carbonate rock formations [106].

b. Treatment of produced emulsions As the injected chemicals of ASP slug breakthrough in production well, the 
strong synergetic interaction between the chemicals attracts them to the oil/water interface, thus, inducing a stable emulsion. Unlike conventional emulsion, the produced emulsions are thermodynamically stable and not easy to demulsify as they remain concentrated at the oil-water interfaces. The enhanced emulsion stability is caused by electrostatic and steric effects of the injected surfactants, soaps, and polymers. The presence of stable emulsions in the produced fluid from oil wells poses difficulty for the separation and processing in the separator [107].

c. ASP produced water disposal treatment The presence of stable emulsion in the produced water from ASP flooding process is a cause of concern during the treatment of produced water to meet disposal requirement. This is because the emulsified water exhibits a high oily and suspended solids content, which is difficult to dispose due to the adsorption of injected chemicals on the surface of the oil droplets. The necessity to meet the specified standard for disposal of produced water aboard makes the overall process strenuous $[10,107]$.

\section{Recent trends in chemical EOR}

The new trends in chemical EOR includes the application of nanotechnology, the trial of new chemical substance such as ionic liquids, and the development of improved technology from previously known chemical EOR methods.

\section{Application of nanotechnology}

The application of nanotechnology has proffered solutions to some of the issues ravaging the oil and gas industry ranging from petroleum exploration, drilling and completion, flow assurance problems, hydraulic fracturing and EOR. Nanoparticles have recently found application in chemical EOR due to their ability to react with amphiphilic and macromolecular components of EOR chemicals. They form polymeric nanofluids, nanosurfactants, and nano-stabilized foam when reacted with polymers, surfactants and foams, respectively. The newly formed suspension (or composite materials as the case maybe) exhibit sterling and fascinating properties different from the individual component of the material. In polymer molecules, the presence of nanoparticles improves rheological behaviour and prevents degradation of the polymer molecules. Nanoparticle-stabilized foams are found to have a longer half-life. Additionally, the lamellae bubbles are thicker, hence, thermodynamically stable. Nanosurfactants have ultra-low IFT due the irreversible adsorption of nanoparticles at the interface. Overall, nano-chemicals have lower adsorption during the various tests conducted in porous media. Hence, they have been deemed more suitable and tagged as the next revolution for the application of chemical EOR methods [14, 108, 109].

\section{Nanofluid flooding}

Though most works are still in the laboratory and pilot scale, nanoparticles have been tested for their application in EOR. Different laboratory studies show that nanofluids (mixture of nanoparticles with aqueous solution) can recover trapped oil from reservoir efficiently. During its use for EOR purposes, nanoparticles are either used as nanodispersion (nanoparticle in aqueous water, alcohols or brine) or as nanofluids (nanoparticle in chemical base fluids, e.g., surfactant or polymer) to enhance their fluid property and make them more efficient for EOR application purposes. Recently, the field application of nanofluid flooding for EOR has been reported in Cupiagua Sur field, TN field, Castilla and Chichimene field of Colombia with a higher oil recovery for all field trials [28].

\section{Mechanism of nanofluid flooding}

When applied for EOR purposes, nanofluids operate in similitude to surfactants and improve oil production through the mechanisms of wettability alteration, IFT reduction and emulsion stabilization.

Wettability alteration Like surfactants, nanoparticles alter the wettability of porous media [110]. Wasan and Nikolov elucidated the mechanism of wettability alteration by nanofluids and termed it structural disjoining pressure, the ability of the fluids to spread on the rock surface due to an imbalance of the interfacial forces among the aqueous, oleic and solid surface [111]. Initially, the nanoparticles are ordered within the fluid resulting in the formation of a wedge film between the solid and oil sub-

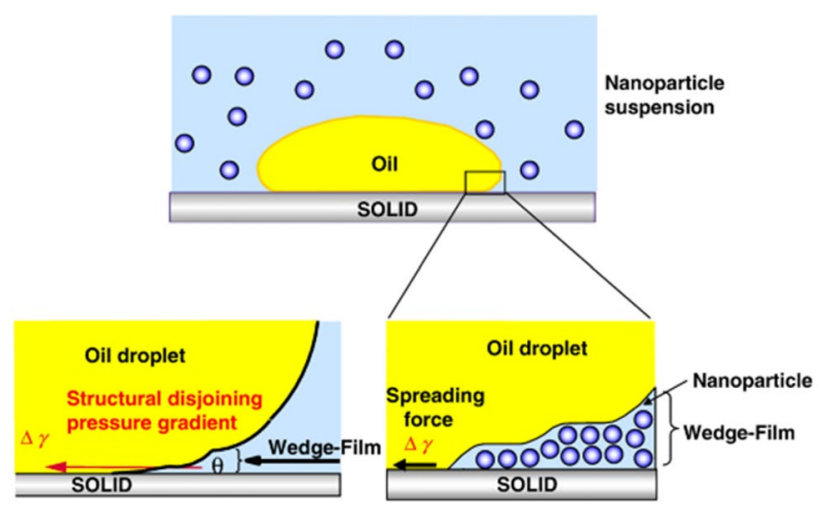

Fig. 12 Ordering of nanoparticle in the wedge film resulting in structural disjoining pressure gradient at the wedge vertex [112] 
strate (see Fig. 12) [114]. Thereafter, due to the nanoparticle structuring in the wedge confinement, the film tension (structural disjoining pressure) near the vertex is high. As the structural disjoining pressure increases, it causes the nanofluid to spread at the wedge tip, thus, enhancing the spreading behaviour of the nanofluid [112]. McElfresh et al. [113] attributed the energies that drive this mechanism in nanofluids to the inherent Brownian motion and electrostatic repulsion among the nanoparticles within the fluid gradient at the wedge vertex [114].

Onyekonwu et al. studied the wettability alteration potential of three polysilicon nanoparticles (PSNP): lipophobic and hydrophilic PSNP (LHPN), hydrophobic and lipophilic PSNP (HLPN), and neutrally wet PSNP (NWPN), with the aim of improving oil recovery. LHPN changes the wettability of oil-wet to water-wet and made water-wet rocks strongly water-wet. Meanwhile, NWPN alters the wettability of the rock surface to a neutral state because of the presence of hydrophilic and hydrophobic moieties [115]. Hendraningrat et al. observed that the use of hydrophilic nanoparticles resulted in wettability alteration of Berea core plugs and as the concentration of nanoparticles increases, the contact angle of the aqueous phase decreases further, and consequently an increase in water wetness of the core plug [116].

IFT reduction In addition to its wettability alteration mechanism, nanoparticles can lower the IFT between oil and the displacing fluid. Using a glass micromodel, Torsater et al. observed a reduction in dynamic IFT in their experimental study of hydrophilic nanoparticles [117]. Likewise, Roustaei et al. conducted an experimental investigation of hydrophobic and lipophilic polysilicon (HLP) and naturally wet polysilicon (NWP) nanoparticles for EOR [118]. The result shows a decrease in oil-water IFT from $26.3 \mathrm{mN} / \mathrm{m}$ to 1.75 $\mathrm{mN} / \mathrm{m}$ and $2.55 \mathrm{mN} / \mathrm{m}$ after application of HLP and NWP nanofluids, respectively. Applying spinning drop method, Li et al. observed that IFT decreased between synthetic oil and brine/nanofluid after injecting nanofluid onto several waterwet Berea sandstone core plugs [119]. The ability of nanoparticles to lower IFT means the frictional force between the water-phase and oil phase will decrease, capillary number will be greatly improved and consequently oil recovery.

Emulsion stabilization Addition of nanoparticles to oilwater system influences phase behaviour of the system, thereby, inducing viscous emulsion which are very stable. As compared to emulsions stabilized by surfactant molecules which can be dynamically adsorbed or desorbed from the interface, emulsions generated by solid nanoparticles have stronger tendency to irreversibly adsorb at the interface (see Fig. 13). The irreversible adsorption at the interface protects the emulsion droplet formed against floccula-

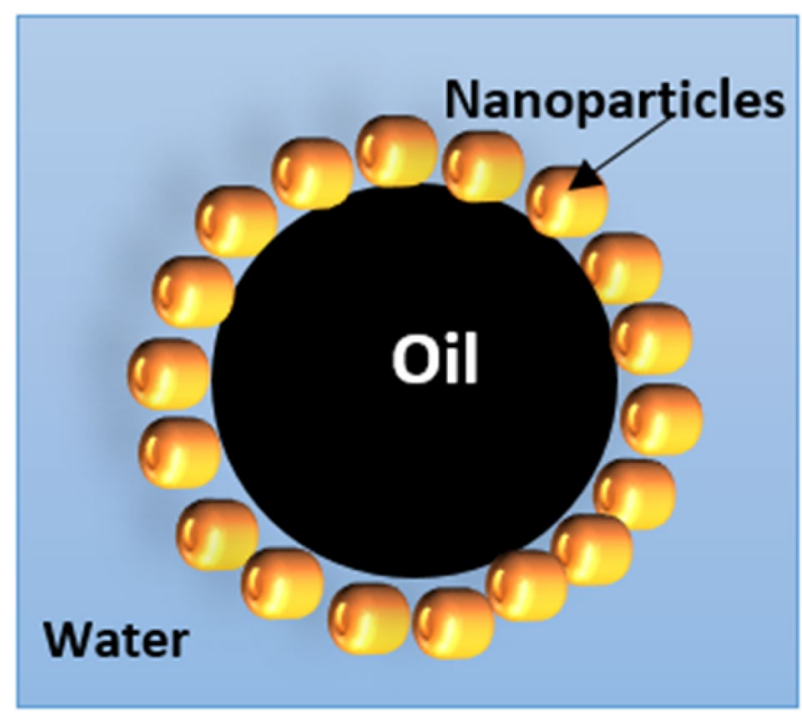

Fig. 13 Nanoparticle-stabilized emulsions [30]

tion and coalescence, thus, inducing stability [30]. In porous media, due to their stable structure, nanoparticle-stabilized emulsions exhibit flow divergence by plugging pathways of fingers in waterflooded reservoir, hence, increasing vertical and areal sweep efficiency of the reservoir [120].

\section{Types of nanofluid flooding}

Polymeric nanofluids Polymeric nanofluid utilize the synergistic combination of nanoparticles and polymer macromolecules, hence, displaying sterling and fascinating properties for EOR purposes. Depending on the solution conditions, their combination interacts through several forces, namely electrostatic and van der Waals interaction, hydrogen bonding, hydrophobic interaction, steric repulsion, and electrosteric repulsion [121]. The newly formed novel materials exhibit improved thermal properties, salt-tolerant behaviour, improved rheological properties and high-performance characteristics that ease recovery of oil from the reservoir. The rheological properties of the polymer increase in the presence of nanoparticles. Besides, the nanoparticle stability also improved in the presence of the polymer solution [122]. Ion-shielding effect of the nanoparticle in polymeric nanofluid is responsible for their stability in high-salinity conditions [123]. Meanwhile, thermal vibrations of the nanoparticle in high temperature occurs which improves the solution conductivity [124]. Hence, the use of polymeric nanofluids are proffered and deemed more suitable for applications in high-salinity and high-temperature reservoirs [25]. Table 3 lists the laboratory results for the application of polymeric nanofluids for EOR indicating their suitability for oilfield applications. 
Table 3 Laboratory results of oil recovery applications by polymeric nanofluid [30]

\begin{tabular}{|c|c|c|c|c|c|c|c|}
\hline References & NP type & $\begin{array}{l}\text { Polymer/copolymer } \\
\text { type }\end{array}$ & PNF conc. (ppm) & Brine/conc. & Temp $\left({ }^{\circ} \mathrm{C}\right)$ & Porous media type & $\begin{array}{l}\text { Incremental oil } \\
\text { recovery }(\%)\end{array}$ \\
\hline$[161]$ & $\mathrm{SiO}_{2}$ & PEOMA & 10,000 & $1.0 \mathrm{wt} \% \mathrm{NaCl}$ & 30 & Berea sandstone & 19.5 \\
\hline$[162]$ & $\mathrm{SiO}_{2}$ & PAMAM & 1500 & $\begin{array}{l}10 \text { wt } \% \mathrm{NaCl}, 0.15 \\
\text { wt } \% \mathrm{MgCl}_{2} 0.10 \text { wt } \% \\
\mathrm{CaCl}_{2}\end{array}$ & 90 & Berea sandstone & 16.3 \\
\hline [163] & $\mathrm{SiO}_{2}$ & Prop-2-enamide/AM & 8000 & - & 80 & Quartz sand & 21.0 \\
\hline [164] & $\mathrm{SiO}_{2}$ & AMPS & 50,000 & - & 80 & Quartz sand & 23.22 \\
\hline$[165]$ & $\mathrm{SiO}_{2}$ & PEG & 10,000 & - & 80 & Glass micromodel & 20.0 \\
\hline [166] & $\mathrm{SiO} 2$ & $\mathrm{MeDiC}_{8} \mathrm{AM}$ & 1500 & $\begin{array}{l}12 \mathrm{wt} \%(\mathrm{NaCl} \text { and } \\
\left.\mathrm{CaCl}_{2}\right)\end{array}$ & 82.3 & Sandstone & 20.0 \\
\hline [167] & $\mathrm{SiO}_{2}$ & $\mathrm{AMC}_{12} \mathrm{~S}$ & 1100 & $18 \mathrm{wt} \%$ & 110 & Sandstone & 24.0 \\
\hline [168] & $\mathrm{SiO}_{2}$ & AA/AM & 2000 & $\begin{array}{l}2 \mathrm{wt} \% \mathrm{NaCl}, 0.18 \text { wt } \% \\
\mathrm{CaCl}_{2}\end{array}$ & 65 & Sandstone & 20.1 \\
\hline [169] & $\mathrm{SiO}_{2}$ & $\mathrm{PA}-\mathrm{S}$ & 3000 & $\begin{array}{l}5 \mathrm{wt} \% \mathrm{NaCl}, 2 \mathrm{wt} \% \\
\mathrm{CaCl}_{2}\end{array}$ & 25 & - & 12.77 \\
\hline$[170]$ & $\mathrm{SiO}_{2}$ & AM/AA & 1500 & - & - & - & 18.84 \\
\hline$[171]$ & $\mathrm{SiO}_{2}$ & HPAM & 1000 & $\begin{array}{l}2.4 \mathrm{wt} \%\left(\mathrm{NaCl}, \mathrm{CaCl}_{2} \text {, }\right. \\
\left.\quad \mathrm{MgCl}_{2}\right)\end{array}$ & 25 & Glass micromodel & 10.0 \\
\hline$[22]$ & $\mathrm{SiO}_{2}$ & HPAM & 800 & $3 \mathrm{wt} \% \mathrm{NaCl}$ & - & Glass micromodel & 10.0 \\
\hline [172] & $\mathrm{TiO}_{2}$ & HPAM & - & $\begin{array}{c}2 \text { wt } \%\left(\mathrm{NaCl}, \mathrm{CaCl}_{2},\right. \\
\mathrm{MgCl}_{2} \cdot 6 \mathrm{H}_{2} \mathrm{O}, \\
\left.\mathrm{Na}_{2} \mathrm{HCO}_{3}\right)\end{array}$ & - & Sandstone & $4.0 *$ \\
\hline [173] & MMT Clay & HPAM & 1000 & $\begin{array}{l}10 \mathrm{wt} \%\left(\mathrm{NaCl}, \mathrm{CaCl}_{2}\right. \\
\left.\mathrm{MgCl}_{2}\right)\end{array}$ & 90 & Quartz sand & 33.0 \\
\hline [12]. & $\begin{array}{l}\mathrm{SiO}_{2} \\
\text { Clay }\end{array}$ & HPAM & 1500 & $\begin{array}{l}2.0 \mathrm{wt} \%\left(\mathrm{NaCl}, \mathrm{CaCl}_{2},\right. \\
\left.\quad \mathrm{MgCl}_{2} \cdot 6 \mathrm{H}_{2} \mathrm{O}\right)\end{array}$ & NS & Sandstone & 13.0 \\
\hline [174] & $\mathrm{SiO}_{2}$ & HPAM & 600 & $\begin{array}{l}6.0 \mathrm{wt} \%\left(\mathrm{NaCl}, \mathrm{CaCl}_{2}\right. \\
\mathrm{MgCl}_{2} \cdot 6 \mathrm{H}_{2} \mathrm{O} \mathrm{Na} \mathrm{Na}_{2} \mathrm{SO}_{4} \\
\left.\mathrm{Na}_{2} \mathrm{HCO}_{3}\right)\end{array}$ & 80 & Quartz sand & 10.54 \\
\hline
\end{tabular}

*Heavy oil

Surfactant nanofluid The combination of nanoparticle and surfactant has also been prodigiously investigated for EOR applications. Their mixture modifies the properties of the reservoir by inducing wettability change and adsorb at the oil-water interface through the surface-active groups inherent in their component [109]. Hence, surfactant nanofluids, otherwise referred to as nanosurfactants, achieve ultra-low IFT and generate stable emulsions where precursor nanoparticles or surfactants separately do not [125]. Besides, adsorption interaction of the surfactant on the nanoparticles surface lowers the adsorption of surfactant on rock pores via competitive adsorption mechanism [126, 127]. Nonetheless, the relative concentration ratio between the nanoparticle and the surfactant is paramount and defines the properties of the system. A lower concentration ratio between the surfactant and the nanoparticle implies that only a small portion of surfactant is available to coat the nanoparticle surface. On the other hand, large concentration ratio will results in a bilayer of surfactant forming on the nanoparticle surface [109, 125]. Table 4 summarizes the experimental results of the application of nanosurfactant for recovery of oil.
Nanoparticle/nanoparticle-surfactant foam Foam stability in porous media largely depends on the stability of its lamellae [128]. Nanoparticles, either by their addition into the foaming surfactant solution or through their surface wettability modifications has recently provided an alternative to generate stable foam at harsh reservoir conditions [129]. Nanoparticles performed similar roles in nanoparticlesstabilized foams and foams stabilized by nanoparticles-surfactant mixtures. Most of the limitations of surfactant-stabilized foams can be circumvented using nanoparticles as the stabilizing components of the foam. Nanoparticles are solids and the foams they stabilize are expected to be highly resistant to unfavourable reservoir conditions of high salinity and temperatures [130]. The stability of nanoparticlestabilized foam does not depend on the modification of the polymer chain or surfactant chemical structure like conventional chemical-stabilized foams [131].

Three major mechanisms of foam stabilization by nanoparticles have been identified as: (1) particle detachment energy; (2) maximum capillary pressure of coalescence; (3) the kinetic of film drainage. Nanoparticles can adsorb at 
Table 4 Laboratory results of oil recovery applications by nanosurfactant

\begin{tabular}{|c|c|c|c|c|c|c|c|c|c|}
\hline Nanoparticle & Surfactant & NP conc. & $\begin{array}{l}\text { Surfactant } \\
\text { conc. }\end{array}$ & Base fluid & Oil type & $\begin{array}{l}\text { Porous } \\
\text { media type }\end{array}$ & $\begin{array}{l}\text { Mechanism } \\
\text { of recovery }\end{array}$ & $\mathrm{RF}$ & References \\
\hline $\mathrm{SiO}_{2}$ & SDS & $0.1-0.5 \mathrm{wt} \%$ & $0.2 \mathrm{wt} \%$ & $\begin{array}{l}\text { Deionized } \\
\text { water }\end{array}$ & Crude oil & Quartz sand & $\begin{array}{l}\text { IFT, com- } \\
\text { petitive } \\
\text { adsorption }\end{array}$ & $4.68 \% \mathrm{IO}$ & [126] \\
\hline $\mathrm{SiO}_{2}$ & $\begin{array}{l}\text { Alfoterra, } \\
\text { Soloterra }\end{array}$ & $0.1-0.8 \mathrm{wt} \%$ & $\begin{array}{l}0.005-0.2 \\
\text { wt } \%\end{array}$ & Brine & Crude oil & $\begin{array}{l}\text { Dolomite, } \\
\text { limestone }\end{array}$ & IFT, WA & $\begin{array}{c}37-45 \% \\
\text { OOIP }\end{array}$ & {$[175]$} \\
\hline $\mathrm{SiO}_{2}$ & TX-100 & $0.1 \mathrm{wt} \%$ & $0.1 \mathrm{wt} \%$ & Brine & $\begin{array}{l}\text { Crude } \\
\text { oil + kero- } \\
\text { sene }\end{array}$ & Sandstone & IFT, WA & $8 \% \mathrm{IO}$ & [176] \\
\hline $\mathrm{SiO}_{2}$ & CTAB & $\begin{array}{c}0.05-0.5 \\
\text { wt } \%\end{array}$ & $0.1 \mathrm{wt} \%$ & Brine & Heavy oil & Micromodel & ES & $\begin{array}{c}17.4-38 \% \\
\text { OOIP }\end{array}$ & [177] \\
\hline $\mathrm{SiO}_{2}$ & SDS & $0.25 \mathrm{wt} \%$ & $1 \mathrm{wt} \%$ & Brine & Heavy oil & Mircomodel & IFT, ES & $5 \% \mathrm{IO}$ & [178] \\
\hline $\mathrm{SiO}_{2}$ & $\begin{array}{l}\text { Non-ionic } \\
\text { Tween } 20\end{array}$ & $2-4 \mathrm{wt} \%$ & $0.74 \mathrm{wt} \%$ & $\begin{array}{l}\text { Deionized } \\
\text { water }\end{array}$ & Heavy oil & Micromodel & IFT, ES & $18-39 \%$ & [179] \\
\hline $\mathrm{SiO}_{2}$ & CTAB & $0-5 \mathrm{wt} \%$ & $0.09 \mathrm{mM}$ & $\begin{array}{l}\text { Distilled } \\
\text { water }\end{array}$ & Heptane & - & IFT & - & {$[180]$} \\
\hline $\mathrm{SiO}_{2}$ & $\begin{array}{l}\text { Lecithin } \\
\text { NaCAS } \\
\text { Tween } 60\end{array}$ & - & $\begin{array}{c}0.01-1.4 \\
\text { wt } \%\end{array}$ & - & Vegetable oil & - & IFT, WA & - & [181] \\
\hline $\begin{array}{l}\text { Hydrophilic } \\
\text { and hydro- } \\
\text { phobic } \\
\mathrm{SiO}_{2}\end{array}$ & SDS & 0.1 wt $\%$ & $\begin{array}{c}0.01-0.6 \\
\text { wt } \%\end{array}$ & $\begin{array}{l}\text { Deionized } \\
\text { water }\end{array}$ & - & Sandstone & $\begin{array}{l}\text { IFT, adsorp- } \\
\text { tion reduc- } \\
\text { tion }\end{array}$ & - & [182] \\
\hline $\begin{array}{l}\text { Non-ferrous } \\
\text { metal }\end{array}$ & Sulphanole & $0.001 \mathrm{wt} \%$ & $\begin{array}{l}0.0078-0.05 \\
\text { wt } \%\end{array}$ & - & Heavy oil & - & IFT, WA & $12-22 \% \mathrm{IO}$ & [183] \\
\hline $\mathrm{Al}_{2} \mathrm{O}_{3}$ & PRNS & $0.001-1 \mathrm{wt} \%$ & & $\begin{array}{l}\text { Distilled } \\
\text { water }\end{array}$ & Heavy oil & Sandstone & WA & $33 \% \mathrm{IO}$ & [184] \\
\hline $\begin{array}{l}\text { Fumed } \mathrm{SiO}_{2} \\
\text { Hydrophobic } \\
\quad \mathrm{SiO} 2\end{array}$ & $\begin{array}{c}\text { Ziziphus } \\
\text { spina- } \\
\text { christi }\end{array}$ & $\begin{array}{c}0.05-0.2 \\
\text { wt } \%\end{array}$ & $0.1-8$ wt $\%$ & $\begin{array}{l}\text { Deionized } \\
\text { water }\end{array}$ & - & $\begin{array}{l}\text { Shale sand- } \\
\text { stone }\end{array}$ & $\begin{array}{r}\text { Adsorption } \\
\text { reduction }\end{array}$ & - & [185] \\
\hline $\mathrm{ZrO}_{2}$ & SDS, CTAB & $0.01 \mathrm{wt} \%$ & $0.1-0.4 \mathrm{wt} \%$ & $\begin{array}{l}\text { Distilled } \\
\text { water }\end{array}$ & Heavy oil & Micromodel & IFT, WA & - & [186] \\
\hline $\mathrm{ZrO}_{2}, \mathrm{NiO}$ & $\begin{array}{r}\text { TX-100, } \\
\text { CTAB }\end{array}$ & $\begin{array}{l}0.004-0.05 \\
\text { wt } \%\end{array}$ & $0.1-3.2 \mathrm{wt} \%$ & $\begin{array}{l}\text { Deionized } \\
\text { water }\end{array}$ & - & Limestone & WA & - & [129] \\
\hline $\mathrm{SiO}_{2}$ & SDS, PAM & $0.5-2.0 \mathrm{wt} \%$ & $0.14 \mathrm{wt} \%$ & $\begin{array}{l}\text { Deionized } \\
\text { water }\end{array}$ & Medium oil & Sandstone & IFT, WA & $60 \%$ OOIP & [187] \\
\hline $\mathrm{ZrO}_{2}$ & $\begin{array}{l}\text { Non-ionic } \\
\text { Tween and } \\
\text { Span }\end{array}$ & $\begin{array}{c}0.05-0.1 \\
\text { wt } \%\end{array}$ & - & $\begin{array}{l}\text { Distilled } \\
\text { water }\end{array}$ & Heavy oil & Carbonate & WA & - & [188] \\
\hline
\end{tabular}

the gas-liquid interface of foam with very strong adhesion energy that makes their attachment irreversible. This attachment energy has been reported to be many times larger than that of a surfactant molecule [132-134]. The relationship between the energy required to remove the particle from the interface $W_{r}$, (also known as adsorption or detachment energy), the radius of the particle, $R$, the interface surface tension $\gamma \alpha \beta$ and the particle contact angle at the interface, $\theta$, is given as:

$W_{\mathrm{r}}=\pi R^{2} \gamma_{\alpha \beta}(1 \pm \cos \theta)^{2}$.

Equation (4) shows that, at favourable intermediate contact angles (between $60^{\circ}$ and $90^{\circ}$ ), the detachment energy will be very large. The particles will be strongly and irreversibly adsorbed on the gas-liquid interface making them to form more stable foam than the surfactants which possess less adsorption energy due to their smaller sizes and less energetic participation at the fluid-fluid interface [135-137]. However, very low detachment energy will be obtained at extremely low and high contact angles (i.e., $\leq 30^{\circ}$ and $\geq 150^{\circ}$ ) which will make the particles to be either highly hydrophilic or highly hydrophobic, thus making them unable to generate and stabilize strong foams [94]. The stability of the nanoparticles-stabilized foams is improved by the steric barrier provided to foam thinning by the adsorption of nanoparticles on bubble surfaces which increases the maximum capillary pressure the foam lamellae can experience without rupturing (see Fig. 14). 


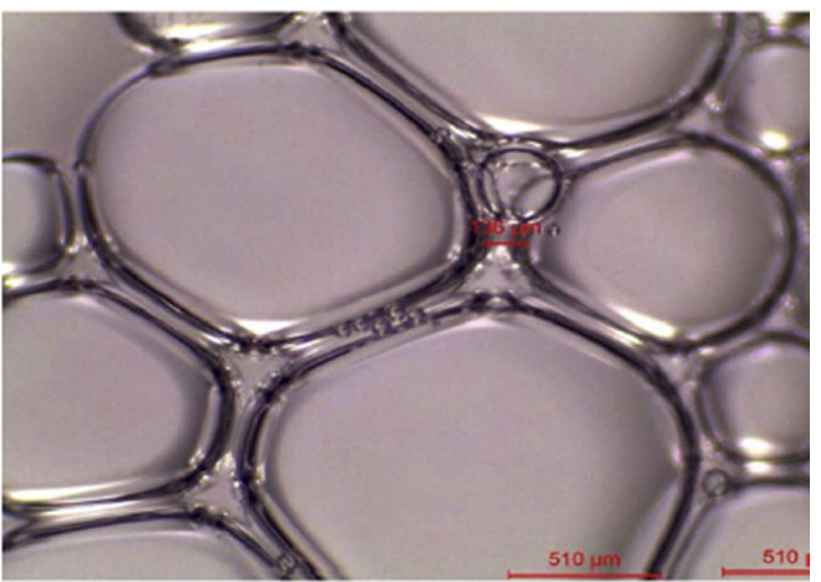

Fig. 14 Foams stabilized by nanoparticles [89]

Foam stability is enhanced by a three-dimensional network structure formed by the stratification of the nonadsorbing nanoparticles in the intervening thin film separating the dispersed phase. Sun et al. studied the influence of nanoparticles on generation, propagation and stability of $\mathrm{SiO}_{2} / \mathrm{SDS}$-stabilized foam in micromodels and sandpack porous media [134]. From the results of their studies, the mechanism of $\mathrm{SiO}_{2} / \mathrm{SDS}$ foam stabilization by silica nanoparticles in the presence of oil is explained with Fig. 15. In the case of SDS-stabilized foam, the shape of the oil droplet could not be changed by the foam because the microforce acting on the oil droplet was small. This subsequently leads to bubble ruptures and coalescence leaving substantial amount of oil trapped in the porous media. In the case of $\mathrm{SiO}_{2} / \mathrm{SDS}$ foam, large amount of oil was displaced by the foam due to the higher microforce acting on the oil droplet. The higher microforce was attributed to the enhanced viscoelasticity of the bubble surface by the attached nanoparticles. Table 5 summarizes laboratory and experimental results of nanoparticles-stabilized and nanoparticle-surfactant-stabilized foams.

Smart nano-waterflooding The injection of nanoparticles dispersed in water, brine, and/or alcohol (nanodispersion) is referred to as smart nano-waterflooding [138]. This process relies on the large surface area and other inherent properties of the injected nanoparticle to boost oil recovery. For example, $\mathrm{SiO}_{2}$ nanoparticles is very efficient for IFT reduction at the oil-water interface. Meanwhile, nanoparticles such as aluminium oxide $\left(\mathrm{Al}_{2} \mathrm{O}_{3}\right)$, copper oxide $(\mathrm{CuO})$, iron oxide $\left(\mathrm{Fe}_{2} \mathrm{O}_{3}\right)$, nickel oxide $(\mathrm{NiO})$ and magnesium oxide $(\mathrm{MgO})$ are efficient for reducing viscosity of the oleic phase in the porous media. Additionally, most of these nanoparticles can alter wettability of the rock surface and/or increase the viscosity of the injectant when injected with waterflood, hence, their ability to improve oil recovery (see Table 6).

\section{Ionic liquids application for EOR}

Due to high cost and environmental issues associated with the use of conventional chemical EOR, ionic liquids, a molten salt has gained tremendous attention for applications in EOR due to their green nature. Ionic liquids typically consist of organic cations and organic or inorganic anions and are classified accordingly [139]. They exhibit several useful features such as good solubility, high ionic conductivity, reusability, and possess good thermal stability (see Tables 7, 8) [140]. Depending on the anions, cations and alkyl group composition of ionic liquids, their properties vary and their efficiency/effectiveness are altered accordingly. For example, the viscosity incremental factor of ionic liquids during their use as injectants depends on the length of the alkyl group present. Other mechanism of ionic liquid application includes wettability alteration and IFT reduction due to their surface-active nature and micelle formation property [141, 142].

As compared to surfactants, laboratory works shows ionic liquids are better alternatives as they reduce IFT at high-salinity and high-temperature conditions [143-145]. Besides, ionic liquids have a better ability to self-organize during their aggregation behaviour at the interface. Moreover, ionic liquids show better capacity to stabilize emulsions. However, the shortcoming of the novel application of this chemical for EOR is that when its constituent contains halogen-anions, they cross the limit of greenness. Degradation of such ionic liquids produces hydrogen
Fig. 15 Mechanisms of oil droplet mobilization by a SDS foam, and $\mathbf{b ~} \mathrm{SiO}_{2}-\mathrm{SDS}$ foam [134]

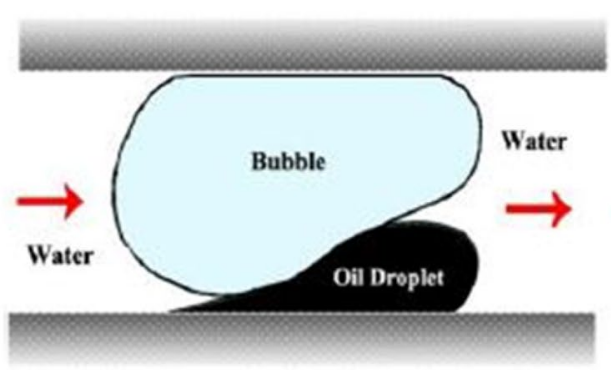

(a)

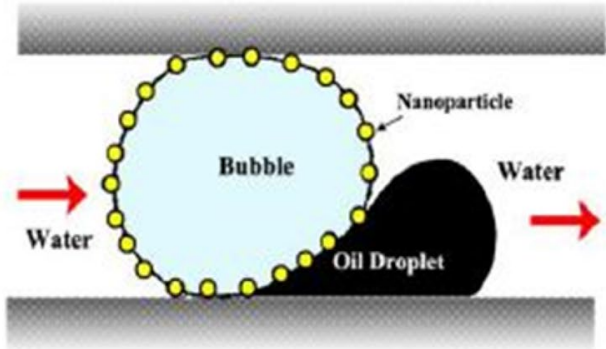

(b) 


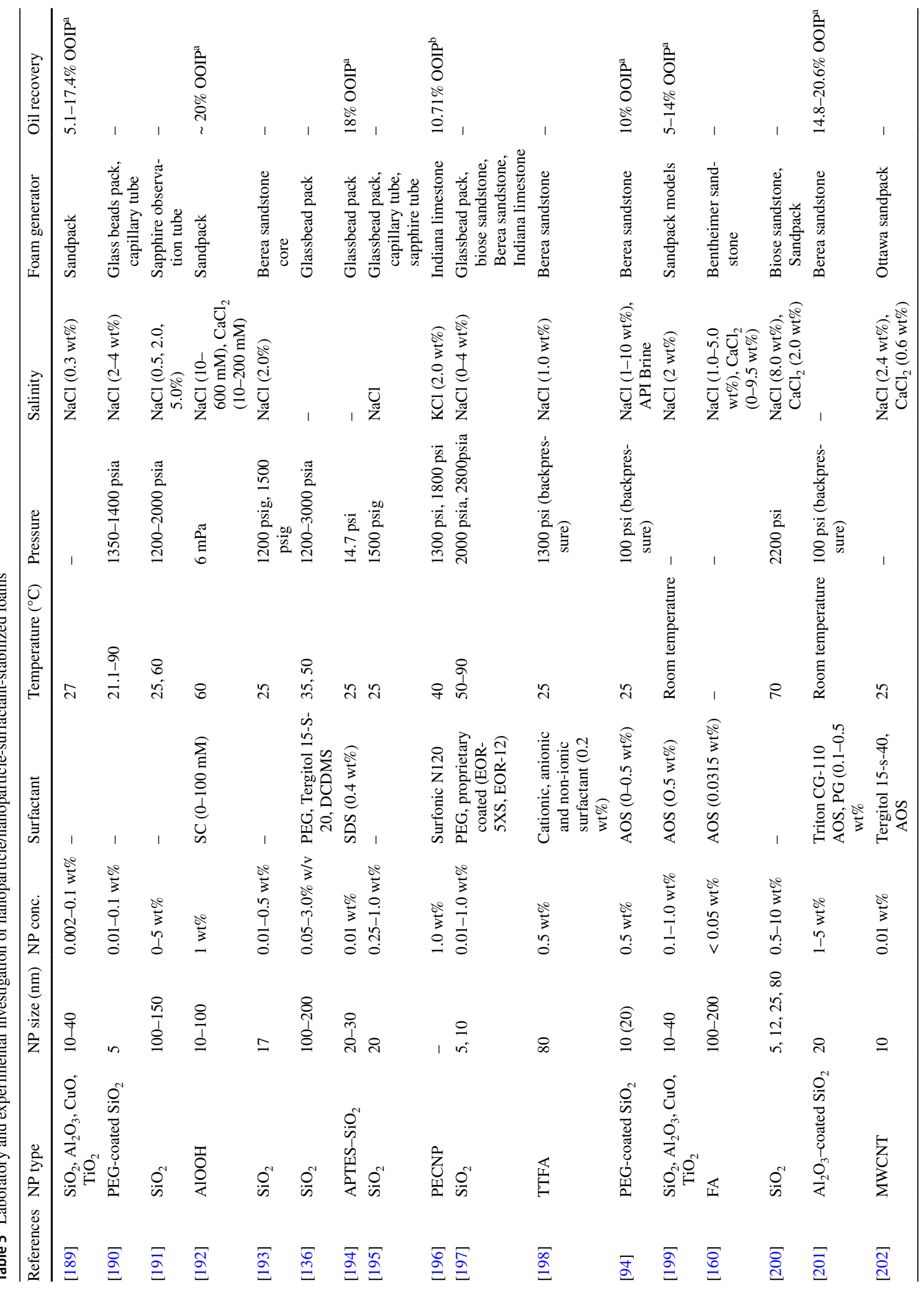




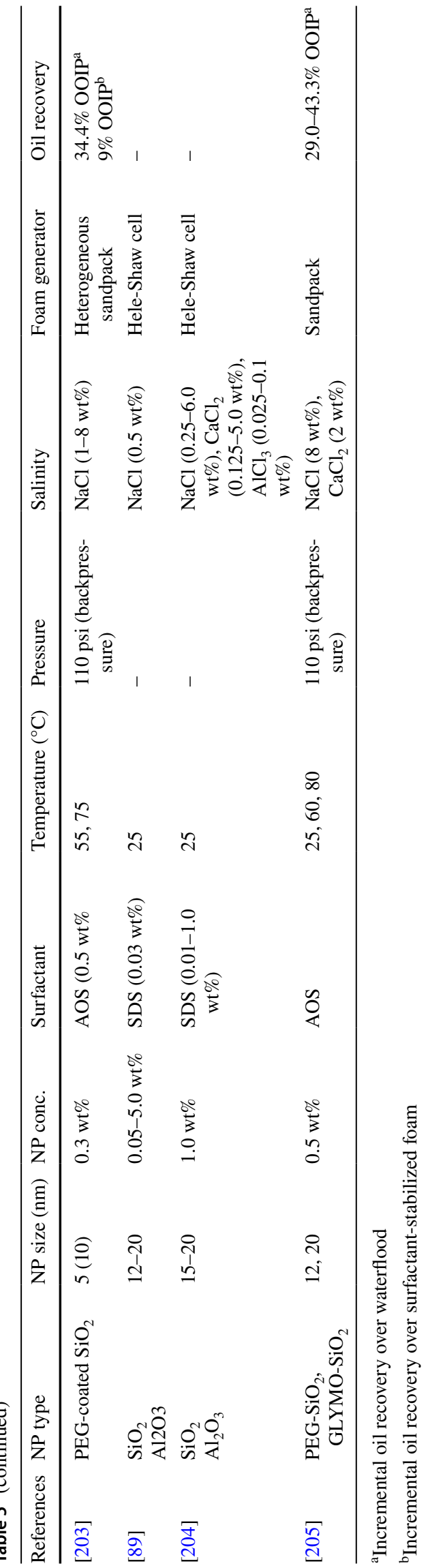

fluoride (HF) and hydrogen chloride $(\mathrm{HCl})$ which are harmful to the environment. Additionally, high adsorption of the ionic liquids was reported during adsorption studies on kaolinite clay at high salinity [146]. Hence, more studies on ionic liquids are required to overcome these limitations for field applications.

\section{Alkaline-cosolvent-polymer (ACP) as a new EOR technology}

Due to the limitations of well researched and previously applied chemical EOR methods, researchers have consistently and are constantly researching into new and viable chemical EOR techniques capable of ensuring higher oil recovery with no downside. Such limitations include but not limited to: (1) alkaline concentration that results in ultralow IFT is often too low for practical purposes and shows poor phase behaviour; (2) The use of AP floods generates highly viscous macroemulsions which results in high pressure gradient and phase trapping; (3) ASP formulations find it difficult to pass stringent aqueous stability tests. More recently, ACP flooding emerged as a new chemical EOR with great prospect and potential compared to conventional EOR methods [147]. ACP floods combine the synergy of low concentration of inexpensive light cosolvents to AP solutions. The synergy of the chemicals improves efficiency of oil recovery in two important ways. Firstly, the addition of cosolvents results in the formation of low-viscosity microemulsion as compared to the undue highly viscous microemulsions of ASP flooding. Lastly, the presence of light cosolvent in the ternary combination greatly improves the phase behaviour in such a way that they can be tailored for a wide range of application. With availability of polymer for mobility control, ACP flooding performs in similitude to ASP while being simpler and more robust [148].

\section{Other challenges of chemical EOR}

Apart from the previously discussed issues of retention of chemical (surfactant and polymer) molecules which poses severe threat for the application of chemical methods of EOR, other challenges encountered by the application of chemical EOR is the expensiveness of the chemicals used during oil recovery and formation damage of subsurface by chemicals.

\section{Formation damage}

Notwithstanding the highly coveted oil recovery during various application of chemical EOR methods, an important limitation of this EOR method is the formation damage issues induced from the retention or reaction of the chemicals in 
Table 6 Summary of oil recovery by smart nano-waterflooding

\begin{tabular}{|c|c|c|c|c|c|c|c|c|c|}
\hline References & NP type & $\begin{array}{l}\text { NP size } \\
(\mathrm{nm})\end{array}$ & NP conc & Base fluid & Salinity & Temp. & $\begin{array}{l}\text { Oil type/ } \\
\text { viscosity }\end{array}$ & Rock type & Oil recovery \\
\hline [206] & $\begin{array}{l}\mathrm{SiO}_{2} \\
\mathrm{Al}_{2} \mathrm{O}_{3} \\
\mathrm{TiO}_{2}\end{array}$ & $10-40$ & $0.005 \mathrm{wt} \%$ & $\begin{array}{l}\text { Deionized } \\
\text { water }\end{array}$ & $\begin{array}{l}\text { Brine } 1 \text { (2 wt } \% \\
\mathrm{NaCl}, 0.2 \\
\text { wt } \% \mathrm{KCl}, 0.2 \\
\text { wt } \% \mathrm{CaCl}_{2}, \\
0.1 \mathrm{wt} \% \\
\left.\mathrm{MgCl}_{2}\right) \\
\text { Brine 2 (3wt } \% \\
\mathrm{NaCl})\end{array}$ & $\begin{array}{l}26,40,50, \\
60{ }^{\circ} \mathrm{C}\end{array}$ & $21.7 \mathrm{cP}$ & Limestone & - \\
\hline [115] & $\begin{array}{l}\text { LHPN, } \\
\text { NWPN, } \\
\text { HLPN }\end{array}$ & $10-60$ & $0.2-0.3 \mathrm{wt} \%$ & $\begin{array}{l}\text { Ethanol and } \\
\text { water }\end{array}$ & $\mathrm{NaCl}(3 \mathrm{wt} \%)$ & Ambient & $\begin{array}{l}\text { Intermedi- } \\
\text { ate oil } \\
\left(28.3^{\circ}\right. \\
\text { API), } \\
\text { light oil } \\
\left(41.1^{\circ}\right. \\
\text { API })\end{array}$ & Sandstone & $0.75-36.67 \%^{\mathrm{a}}$ \\
\hline [207] & HLPN & - & $0.1-0.4 \mathrm{wt} \%$ & Ethanol & $\mathrm{NaCl}(3 \mathrm{wt} \%)$ & Ambient & $33^{\circ} \mathrm{API}$ & Sandstone & $19.31 \%$ \\
\hline [116] & $\mathrm{SiO}_{2}$ & 7 & $\begin{array}{c}0.01,0.05 \\
0.1 \mathrm{wt} \%\end{array}$ & Brine & $\mathrm{NaCl}$ (3 wt\%) & Ambient & $5.1 \mathrm{mPas}$ & Sandstone & $0-14.29 \%$ \\
\hline [208] & $\mathrm{TiO}_{2}$ & - & $\begin{array}{l}0.01 \mathrm{wt} \%, 1 \\
\mathrm{wt} \%\end{array}$ & Brine & $\begin{array}{l}\mathrm{NaCl}(0.5-1.0 \\
\mathrm{wt} \%)\end{array}$ & - & $41.21 \mathrm{cP}$ & Sandstone & $\sim 31 \%$ \\
\hline [209] & $\begin{array}{l}\text { Hydropho- } \\
\text { bic fumed } \\
\mathrm{SiO}_{2}\end{array}$ & 12 & $0.1-0.4 \mathrm{wt} \%$ & Ethanol & $\mathrm{NaCl}(5 \mathrm{wt} \%)$ & Ambient & $\begin{array}{l}33.53^{\circ} \mathrm{API} \\
27.43^{\circ} \mathrm{API}\end{array}$ & Sandstone & $\begin{array}{l}25.43 \% \\
14.55 \%\end{array}$ \\
\hline [210] & $\begin{array}{c}\mathrm{Al}_{2} \mathrm{O}_{3}, \mathrm{TiO}_{2} \\
\mathrm{SiO}_{2}\end{array}$ & $17-40$ & $0.05 \mathrm{wt} \%$ & PVP & $\mathrm{NaCl}(3.0 \mathrm{wt} \%)$ & $\begin{array}{l}25,50 \\
80{ }^{\circ} \mathrm{C}\end{array}$ & $5.1 \mathrm{cP}$ & Sandstone & $19-25 \%$ \\
\hline [211] & $\mathrm{SiO} 2, \mathrm{IIT}$ & 20 & 10 vol. $\%$ & DIW & $\begin{array}{l}\mathrm{NaCl}, \mathrm{KCl}, \\
\mathrm{MgCl}_{2} \cdot 6 \mathrm{H}_{2} \mathrm{O}, \\
\mathrm{CaCl}_{2}, \\
\mathrm{Na}_{2} \mathrm{SO}_{4}, \\
\mathrm{NaHCO}_{3}(2.0 \\
\text { wt } \%)\end{array}$ & $\begin{array}{l}25^{\circ} \mathrm{C} \\
55^{\circ} \mathrm{C}\end{array}$ & $24.58 \mathrm{cP}$ & Sandstone & $50-55 \%$ \\
\hline [212] & $\mathrm{SiO}_{2}, \mathrm{Al}_{2} \mathrm{O}_{3}$ & 87 & $0.1-1.0 \mathrm{wt} \%$ & Brine & $\mathrm{NaCl}(7.0 \mathrm{wt} \%)$ & $\begin{array}{l}25,40 \\
60{ }^{\circ} \mathrm{C}\end{array}$ & $35^{\circ} \mathrm{API}$ & Sandstone & $\begin{array}{l}\mathrm{SiO}_{2}( \\
5.14-13.88 \% \\
\mathrm{Al}_{2} \mathrm{O}_{3}(-8.18 \\
\text { to }-4.65 \%)\end{array}$ \\
\hline [213] & $\begin{array}{c}\mathrm{Fe}_{2} \mathrm{O}_{3} \\
\mathrm{Al}_{2} \mathrm{O}_{3} \\
\mathrm{SiO}_{2}\end{array}$ & - & $0.01 \mathrm{wt} \%$ & Brine & $\begin{array}{c}\text { Brine A }(3.0 \\
\text { wt } \%) \\
\text { Brine B }(1.5 \\
\mathrm{NaCl}, 1.0 \\
\mathrm{CaCl}_{2}, 0.5 \\
\left.\mathrm{MgCl}_{2}\right)\end{array}$ & - & $5.12 \mathrm{cP}$ & Sandstone & $0.9-9.49$ wt $\%$ \\
\hline [214] & $\mathrm{SiO}_{2}$ & 7 & $\begin{array}{c}0.01,0.05 \\
0.1 \mathrm{wt} \%\end{array}$ & Brine & $\mathrm{NaCl}(3.0 \mathrm{wt} \%)$ & - & $5.1 \mathrm{cP}$ & Sandstone & $4.26-5.32 \%$ \\
\hline [215] & $\mathrm{SiO}_{2}$ & 7 & $\begin{array}{c}0.05-0.5 \\
\text { wt } \%\end{array}$ & Brine & $\mathrm{NaCl}(3.0 \mathrm{wt} \%)$ & - & $15.3 \mathrm{cP}$ & Sandstone & $5.0-15 \%$ \\
\hline [216] & $\mathrm{SiO}_{2}$ & $20-70$ & $0.1-0.6 \mathrm{wt} \%$ & Brine & $\mathrm{NaCl}(5.0 \mathrm{wt} \%)$ & Ambient & $33^{\circ} \mathrm{API}$ & Carbonate & $\begin{array}{l}9-12 \% \\
16-17 \%(24 \mathrm{~h} \\
\text { ageing) }\end{array}$ \\
\hline [217] & $\mathrm{SiO}_{2}$ & 14 & $0.1-5.0 \mathrm{wt} \%$ & $\begin{array}{l}\text { Distilled } \\
\text { water }\end{array}$ & - & - & $19^{\circ} \mathrm{API}$ & $\begin{array}{l}\text { Micro- } \\
\text { model }\end{array}$ & $8.7-26 \%$ \\
\hline [218] & $\mathrm{SiO}_{2}$ & $5-60$ & $0.01-3 \mathrm{wt} \%$ & Brine & $\mathrm{NaCl}(6.5 \mathrm{wt} \%)$ & - & $27.3^{\circ} \mathrm{API}$ & Sandstone & $9.0-19 \%$ \\
\hline
\end{tabular}

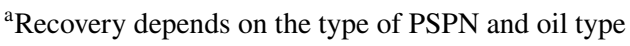


Table 7 Typical properties of modern ionic liquids (sourced from [219])
A salt

Freezing point

Liquidus range

Thermal stability

Viscosity

Dielectric constant

Polarity

Specific conductivity

Vapour pressure

Solvent and/or catalyst

Electrochemical window
Cation or anion quite large

Preferably below $100{ }^{\circ} \mathrm{C}$

Often $>200{ }^{\circ} \mathrm{C}$

Usually high

Normally $<100 \mathrm{cP}$, workable

Implied $<30$

Moderate

$<10 \mathrm{~S} \mathrm{~cm}^{2} \mathrm{~mol}^{-1}$

Usually negligible

Excellent for many organic reactions

$>2 \mathrm{~V}$, even $4.5 \mathrm{~V}$, except for bron-

sted acidic systems the reservoir rock system. Formation damage issues in the reservoir have the propensity to disrupt oil recovery performance, and cause additional technical and cost challenges to oilfields operations and facilities [149]. For example, oilin-water emulsions or water-in-oil emulsions generated from the application of surfactant have been reported to cause severe pore blockage in low permeability reservoirs despite their mobility control potentials. Moreover, the precipitation, phase trapping and adsorption of surfactant molecules on rock pores during their use in reservoirs with hardness brines also results in blockage of pore throat system [149, 150].

Similarly, cases of hydrodynamic retention, mechanical entrapment, adsorption and inaccessible pore volume resulting from the flocculation of polymers at high salinity cause the polymer molecules to accumulate and plug the surface of rock grains [151]. When these situations occur in rock pores with smaller diameter, it is referred to as particle filtration phenomenon. Meanwhile, alkali chemicals used during alkaline flooding have the capacity to dissolve clays and other minerals. During the dissolution process, fines migration and damage emanate from the process which may damage reservoir permeability. Additionally, scale precipitation resulting from the incompatibility of alkali and formation water may deposit on the pore walls of reservoir rock, thereby, causing reduction in permeability or permanent loss of the reservoir [152].

\section{Cost of chemical EOR process}

Generally, chemicals used for this EOR method are low. However, the large-scale field implementation of chemical EOR leads to an astronomical rise in the cost of chemicals required for the process, and consequently an increase in the overall cost of the EOR process. Meanwhile, the choice of an EOR process is based on both efficiency at recovering hydrocarbon and cost-effectiveness. The deficiency of the application of this EOR method is that their selectivity and field implementation is reliant on oil price regime. They are only economical and profitable during higher oil prices. For example, in the year 2015, when oil price crashed to $\sim \$ 40 /$ bbl, most oil fields applying chemical EOR were shut down to prevent losses. In Daqing oil field, to ensure continued ASP flooding process is economical in some of its fields, weak alkali was substituted for strong alkali to lower the cost of the chemical EOR process [153].

\section{Technical solutions to challenges of chemical EOR}

- Adsorption inhibitors To overcome the incessant adsorption of chemicals on rock pores during their use in chemical EOR, the use of adsorption inhibitor otherwise known as sacrificial agent has gained remarkable attention and has been recommended for use during field applications of chemical EOR especially in high-temperature and high-salinity reservoir [83]. The mechanism posited for the efficiency of sacrificial agents during their use in chemical EOR is that the sacrificial agent form complexes with monovalent, divalent and polyvalent cations present in the hardness brine, thus, there is less cations for the chemicals to interact with in the formation fluids. Secondly, there is competition for adsorption sites of the rock pores between the chemicals and sacrificial agent. Meanwhile, the sacrificial agent gets preferentially adsorbed on the rock surface due to their high surface coverage and low desorption. Finally, the sacrificial agent due to their high surface coverage blocks the access of the injected chemicals to other adsorption sites. The overall process increases the amount of chemicals present in the injected slug to effectively recover the residual and bypassed oil, hence, an incremental oil recovery. The most important factor to be considered during the selection of sacrificial agents is that they must be very cheap. Typical examples of sacrificial agents that have been tested and proven to be effective are polyacrylate and lignosulfonates $[83,154,155]$. Lignosulfonates are particularly economically attractive because they are obtained as by-products from pulp industry.

- Conditioning the reservoir The presence of constituent hardness brines attacks and diminishes the functionality of injected chemicals for EOR process. For example, injecting chemicals in Arab-D formation of Ghawar field in Saudi Arabia with total dissolved solids (TDS) $200,000 \mathrm{mg} / \mathrm{l}$ will lead to high retention of the chemicals and make the EOR process unfeasible. To overcome this, researchers have identified the process of conditioning the reservoir prior to injecting the chemicals for EOR. The conditioning process usually involves injection of 
Table 8 Typical examples chemical EOR field projects

\begin{tabular}{|c|c|c|c|c|c|}
\hline Country & Field & Formation & $\begin{array}{l}\text { Chemical EOR } \\
\text { method }\end{array}$ & Chemical type & Incremental oil recovery \\
\hline \multirow[t]{9}{*}{ USA } & Cottonwood Creek & Carbonate & Surfactant & Polyoxyethylene alcohol & - \\
\hline & Bob Slaughter & & Surfactant & Petroleum sulfonate & - \\
\hline & Yates field & Carbonate & Surfactant & Ethoxy sulphate & $30 \mathrm{bbl} /$ day \\
\hline & Tanner & Sandstone & $\begin{array}{l}\text { Surfactant } \\
\text { ASP }\end{array}$ & & - \\
\hline & Sho-Vel-Tum & - & $\begin{array}{l}\text { Surfactant } \\
\text { ASP }\end{array}$ & & - \\
\hline & Cambridge, Minnelusa & Sandstone & $\begin{array}{l}\text { Surfactant } \\
\text { Polymer } \\
\text { ASP }\end{array}$ & PAM & - \\
\hline & West Kiehl & - & ASP & & - \\
\hline & Albrecht & Sandstone & Polymer & HPAM & - \\
\hline & West Cat Canyon & Sandstone & Polymer & HPAM & $66.7 \%$ over WF \\
\hline \multirow[t]{6}{*}{ Canada } & Taber South & - & ASP & & - \\
\hline & Taber Gauconitic & - & ASP & & - \\
\hline & Suffield Caen & - & $\begin{array}{l}\text { Polymer } \\
\text { ASP }\end{array}$ & HAPAM & - \\
\hline & Seal & - & Polymer & HPAM & $5-6 \%$ \\
\hline & Mooney & - & Polymer & HPAM & $12-25 \%$ \\
\hline & Pelican Lake & - & Polymer & HPAM & $5-10 \%$ \\
\hline \multirow[t]{5}{*}{ China } & Daqing & Sandstone & ASP & & 19.4-28\% OOIP \\
\hline & Gudong & Sandstone & ASP & & - \\
\hline & Karamay & Sandstone & ASP & & - \\
\hline & Shengli & Carbonate & ASP & & $16-28 \%$ \\
\hline & Bohai Bay & Sandstone & Polymer & HAPAM & $13.5-20 \%$ OOIP \\
\hline \multirow[t]{3}{*}{ India } & Viraj & Sandstone & $\begin{array}{l}\text { Surfactant } \\
\text { Polymer }\end{array}$ & $\begin{array}{l}\text { Petroleum sulfonate } \\
\text { HPAM }\end{array}$ & - \\
\hline & Jhalora & Sandstone & ASP & & - \\
\hline & Sanand & Sandstone & Polymer & PAM & - \\
\hline \multirow[t]{2}{*}{ Indonesia } & Minas & Sandstone & Surfactant & Petroleum sulfonate & - \\
\hline & Baturaja & Carbonate & Surfactant & & - \\
\hline Germany & Eddesse-Nord & - & Polymer & Xanthan & - \\
\hline Argentina & El Corobo & - & Polymer & HPAM & - \\
\hline Austria & Matzen & - & Polymer & HPAM & - \\
\hline Russia & Romashkino & - & Polymer & HEC & - \\
\hline Oman & Marmul & Sandstone & Polymer & HPAM & $12 \%$ \\
\hline
\end{tabular}

a slug of water (preflush) with specific characteristics and properties. The preflush is targeted at the hardness brines and screens or eliminates them from the reservoir prior to chemical EOR. Nonetheless, there is the need for proper design process when using preflush to determine the adequate and effective preflush for conditioning the reservoir. Major factors taken into consideration during the design process are the TDS of the field, composition of field brine, chemical concentration, chemical slug size, preflush concentration and preflush slug size $[156,157]$.

- Scale inhibitors Scales are common problems during the use of alkali flooding or ASP flooding. Scales form when the alkali present in the injectant reacts with divalent cations such as $\mathrm{Ca}^{2+}$ and $\mathrm{Mg}^{2+}$ present in the formation fluids. The deposition of scales blocks injection or production lines, thereby, lowering oil recovery process. In the reservoir, they reduce formation porosity and permeability by clogging rock pores. The use of scale inhibitors delay, reduce or prevent the formation of scales. Scale inhibitors work by either preventing the formation of scales or suppressing the activity of an already formed scale. When used as scale suppressant, they absorb onto the crystal surface of the already formed scale, thereby, preventing further growth of tiny crystals that precipi- 
tates out of the water. Besides, they coat the surface of the already formed scale crystals, hence, preventing them from adhering to the surface of pipes [106].

- Formulation of cost-effective EOR chemicals As a result of the expensiveness of EOR chemicals, research and development should focus on the formulation of cheap and efficient EOR chemicals from waste and by-products. New efficient biodegradable surfactants are been developed from waste cooking oil, unused coconut oil and palm oil fruit bunch [158, 159]. Additionally, nanoparticles to be used as nanofluid EOR chemicals are been generated from flyash, a waste product of coal firing plants [160]. Finally, the possibility of synthesizing graphene and carbon nanotubes from palm kernel shell, a waste product of palm oil refining is hereby proposed for future research.

\section{Field projects of chemical EOR}

Chemical EOR project has been implemented in various fields across the world. China has the largest field application of chemical EOR with a reported incremental 300,000 $\mathrm{bbl} /$ day of oil. Other countries with high implementation of chemical EOR are USA and Canada. Polymer flooding and ASP flooding have been the most widely used chemicals for field application and most of the oilfields have been sandstone formations. Table 2 summarizes some chemical EOR field projects in various countries across the world.

\section{Conclusion and recommendation}

The article presents an overview of chemical EOR and their applications for ensuring a sustainable energy future. The mechanism of their applications and recent progress have been explored and analysed. The challenges of their application have also been discussed. Field application of conventional chemical EOR have been reported to yield higher oil recovery. Meanwhile, the newly improved nano-chemicals with sterling properties have been limited to laboratory and pilot scale except for a few recently reported field trials in China, Colombia and Ghawar field of Saudi Arabia. This could be attributed to the averseness of oil companies to new technologies and a few uncertainties. These few uncertainties include non-availability of the cost implication of addition of nanoparticles to previously applied conventional chemicals, instability in oil prices, and inadequate data on health and environmental impact of application of nanoparticles. Hence, future research on chemical EOR should address the following areas:
- Cost analysis of nanoparticles and other chemicals Previous researches have focussed on the injection of nanoparticles and associated chemicals and the resultant oil recovery mechanisms and quantity. The cost implication of nanoparticles in the laboratory have been adjudged to be less consequential due to its use in small quantity. However, the field application of these chemicals will require larger quantities and longer times to the tune of years depending on the economic life of the field. Thus, more researches and economic models preferably by petroleum economists that depicts the true economic implication of these novel chemicals at different and feasible oil regimes should be investigated.

- Adsorption and retention behaviour of the novel nanochemicals The focal point of attention for most studies on mechanisms of most nano-chemicals has been on IFT, rheology, wettability alteration, and emulsion stabilization. Very few studies are available on the adsorption behaviour of the nano-chemicals during EOR application. Specifically, the adsorption and retention behaviour of ionic liquids is lacking in literature. An adequate understanding of this mechanism is required due to its impact on the cost implication of the chemical EOR method.

- Toxicity of nanoparticles Presently, there is inadequate research and insufficient information on the health safety and environmental implications of the use of nanoparticles. More research on the toxicity of these chemicals and their impact on humans and the environment is required for further research.

- Modelling for field implementation Though many laboratory studies for the application of nano-chemicals have been presented, an accurate modelling of the behaviour of this chemical is outstanding. This is required to serve as a guideline for design and field implementation of the various nano-chemicals for oil recovery.

- $\mathrm{CO}_{2}$ sequestration potential Most of the nano-chemicals yielded wettability alteration to a more water-wet condition during their laboratory studies. Ability of the nano-chemicals to tether the reservoir to a more waterwet condition is a good omen and indicator of the nanochemicals potential for carbon capture and sequestration (CCS). Hence, the opportunities of utilizing this nanochemicals for CCS should be properly investigated.

- Separation of produced water containing nanoparticles and other chemicals Previously, the development of membranes for the separation of produced water have been tethered towards the separation of produced water, oily components and conventional chemicals. With the new introduction of nano-chemicals and other chemicals such as ionic fluid, the dynamics of the constituents of produced water will change and the previously developed 
membranes may not be efficient. Thus, new membranes capable of effectively and efficiently separating the new constituents of the produced water will be required.

- Opportunities for recycling After production, the opportunities of recycling the produced nano-chemicals should be considered. Additional experiments on reintroduction of previously used chemicals should be tested to determine their efficiency. Finally, a comparative analysis of the cost implication and efficiency of introducing new chemicals and reused chemicals should be made.

\begin{abstract}
Acknowledgements The authors would like to thank the Ministry of Higher Education, Malaysia, and Universiti Teknologi Malaysia for supporting this research through Research Management Grant Vot. nos. Q.J30000.2546.14H50 and R.J130000.7846.4F946.
\end{abstract}

Open Access This article is distributed under the terms of the Creative Commons Attribution 4.0 International License (http://creativeco mmons.org/licenses/by/4.0/), which permits unrestricted use, distribution, and reproduction in any medium, provided you give appropriate credit to the original author(s) and the source, provide a link to the Creative Commons license, and indicate if changes were made.

\section{References}

1. Afolabi, F., Ojo, T., Udeagbara, S., Gbadamosi, A.: Bitumen extraction from tar sands using solvent techniques. Int. J. Sci. Eng. Res. 8, 783-790 (2017)

2. Ogiriki, S.O., Agunloye, M.A., Gbadamosi, A.O., Olafuyi, A.O.: Exploitation of Bitumen from Nigerian tar sand using hot-water/steam stimulation process. Pet. Coal 58, 407-413 (2016). https://doi.org/10.1021/ac010415i

3. Agi, A., Junin, R., Syamsul, M.F., Chong, A.S., Gbadamosi, A.: Intermittent and short duration ultrasound in a simulated porous medium. Petroleum (2018). https://doi.org/10.1016/j. petlm.2018.03.012

4. Gbadamosi, A.O., Kiwalabye, J., Junin, R., Augustine, A.: A review of gas enhanced oil recovery schemes used in the North Sea. J. Pet. Explor. Prod. Technol. 5, 1-15 (2018). https://doi. org/10.1007/s13202-018-0451-6

5. Sorbie, K.S.: Polymer Improved Oil Recovery. Blackie and Son Ltd, London (1991)

6. Gbadamosi, A.O., Junin, R., Manan, M.A., Yekeen, N., Augustine, A.: Hybrid suspension of polymer and nanoparticles for enhanced oil recovery. Polym. Bull. (2019). https://doi. org/10.1007/s00289-019-02713-2

7. Agi, A., Junin, R., Shirazi, R., Afeez, G., Yekeen, N.: Comparative study of ultrasound assisted water and surfactant flooding. J. King Saud. Univ. Eng. Sci. (2018). https://doi. org/10.1016/j.jksues.2018.01.002

8. Hanamertani, A.S., Pilus, R.M., Idris, A.K., Irawan, S., Tan, I.M.: Ionic liquids as a potential additive for reducing surfactant adsorption onto crushed Berea sandstone. J. Pet. Sci. Eng. 162, 480-490 (2018). https://doi.org/10.1016/j.petro 1.2017.09.077

9. Kamal, M.S., Hussein, I.A., Sultan, A.S.: Review on surfactant flooding: phase behavior, retention, IFT, and field applications.
Energy Fuels 31, 7701-7720 (2017). https://doi.org/10.1021/acs. energyfuels. $7 \mathrm{~b} 00353$

10. Olajire, A.A.: Review of ASP EOR (alkaline surfactant polymer enhanced oil recovery) technology in the petroleum industry: prospects and challenges. Energy 77, 963-982 (2014). https:// doi.org/10.1016/j.energy.2014.09.005

11. Thomas, S.: Enhanced oil recovery-an overview. Oil. Gas. Sci. Technol. Rev. l'IFP 63, 9-19 (2007). https://doi.org/10.2516/ ogst:2007060

12. Khalilinezhad, S.S., Cheraghian, G., Karambeigi, M.S., Tabatabaee, H., Roayaei, E.: Characterizing the role of clay and silica nanoparticles in enhanced heavy oil recovery during polymer flooding. Arab. J. Sci. Eng. 41, 2731-2750 (2016). https://doi. org/10.1007/s13369-016-2183-6

13. Levitt, D., Pope, G.A.: Selection and screening of polymers for enhanced-oil recovery. In: Present. SPE Symp. Improv. Oil Recover. 20-23 April. Tulsa, Oklahoma, USA, Society of Petroleum Engineers, pp. 1-18 (2008). https://doi.org/10.2118/11384 5 -ms

14. Sun, X., Zhang, Y., Chen, G., Gai, Z.: Application of nanoparticles in enhanced oil recovery: a critical review of recent progress. Energies 10, 345 (2017). https://doi.org/10.3390/en10030345

15. Samanta, A., Bera, A., Ojha, K., Mandal, A.: Comparative studies on enhanced oil recovery by alkali-surfactant and polymer flooding. J. Pet. Explor. Prod. Technol. 2, 67-74 (2012). https:// doi.org/10.1007/s13202-012-0021-2

16. Zaitoun, A., Makakou, P., Blin, N., Al-Maamari, R.S., AlHashmi, A.-A.R., Abdel-Goad, M.: Shear stability of EOR polymers. SPE-141113-PA. SPE J. 17, 335-339 (2012). https://doi. org/10.2118/141113-pa

17. Kumar, N., Gaur, T., Mandal, A.: Characterization of SPN pickering emulsions for application in enhanced oil recovery. $\mathrm{J}$. Ind. Eng. Chem. 54, 304-315 (2017). https://doi.org/10.1016/j. jiec.2017.06.005

18. Bera, A., Kumar, T., Ojha, K., Mandal, A.: Adsorption of surfactants on sand surface in enhanced oil recovery: isotherms, kinetics and thermodynamic studies. Appl. Surf. Sci. 284, 87-99 (2013). https://doi.org/10.1016/j.apsusc.2013.07.029

19. Samin, A.M., Manan, M.A., Idris, A.K., Yekeen, N., Said, M., Alghol, A.: Protein foam application for enhanced oil recovery. J. Dispers. Sci. Technol. 38, 604-609 (2017). https://doi. org/10.1080/01932691.2016.1185014

20. Ko, S., Huh, C.: Use of nanoparticles for oil production applications. J. Pet. Sci. Eng. 172, 97-114 (2019). https://doi. org/10.1016/j.petrol.2018.09.051

21. Krishnamoorti, R.: Extracting the benefits of nanotechnology for the oil industry. J. Pet. Technol. 58, 24-25 (2006). https://doi. org/10.2118/1106-0024-JPT

22. Yousefvand, H., Jafari, A.: Enhanced oil recovery using polymer/nanosilica. Proc. Mater Sci. 11, 565-570 (2015). https://doi. org/10.1016/j.mspro.2015.11.068

23. Khoja, A.H., Tahir, M., Amin, N.A.S.: Cold plasma dielectric barrier discharge reactor for dry reforming of methane over $\mathrm{Ni} / \gamma-\mathrm{Al} 2 \mathrm{O} 3-\mathrm{MgO}$ nanocomposite. Fuel Process. Technol. 178, 166-179 (2018). https://doi.org/10.1016/j.fuproc.2018.05.030

24. Gbadamosi AO, Junin R, Oseh JO, Agi A, Yekeen N, Abdalla $\mathrm{Y}$, et al.: Improving hole cleaning efficiency using nanosilica in water-based drilling mud. In: Present. SPE Niger. Annual International Conference on Exhibition. 6-8 August, Lagos, Niger., Lagos, Nigeria: Society of Petroleum Engineers, p. 16 (2018). https://doi.org/10.2118/193401-ms

25. Gbadamosi, A.O., Junin, R., Abdalla, Y., Agi, A., Oseh, J.O.: Experimental investigation of the effects of silica nanoparticle on hole cleaning efficiency of water-based drilling mud. J. Pet. Sci. Eng. 172, 1226-1234 (2019). https://doi.org/10.1016/j.petro 1.2018.09.097 
26. Bera, A., Belhaj, H.: Application of nanotechnology by means of nanoparticles and nanodispersions in oil recovery-a comprehensive review. J. Nat. Gas Sci. Eng. 34, 1284-1309 (2016). https://doi.org/10.1016/j.jngse.2016.08.023

27. Agi, A., Junin, R., Gbadamosi, A.: Mechanism governing nanoparticle flow behaviour in porous media: insight for enhanced oil recovery applications. Int. Nano Lett. 8, 1-29 (2018). https://doi. org/10.1007/s40089-018-0237-3

28. Franco, C.A., Zabala, R., Cortés, F.B.: Nanotechnology applied to the enhancement of oil and gas productivity and recovery of Colombian fields. J. Pet. Sci. Eng. 157, 39-55 (2017). https://doi. org/10.1016/j.petrol.2017.07.004

29. Nikolov, A., Wu, P., Wasan, D.: Structure and stability of nanofluid films wetting solids: an overview. Adv. Colloid Interface Sci. 264, 1-10 (2019). https://doi.org/10.1016/j.cis.2018.12.001

30. Gbadamosi, A.O., Junin, R., Manan, M.A., Yekeen, N., Agi, A., Oseh, J.O.: Recent advances and prospects in polymeric nanofluids application for enhanced oil recovery. J. Ind. Eng. Chem. (2018). https://doi.org/10.1016/j.jiec.2018.05.020

31. Yekeen, N., Manan, M.A., Idris, A.K., Padmanabhan, E., Junin, R., Samin, A.M., et al.: A comprehensive review of experimental studies of nanoparticles-stabilized foam for enhanced oil recovery. J. Pet. Sci. Eng. 164, 43-74 (2018). https://doi.org/10.1016/j. petrol.2018.01.035

32. Raffa, P., Broekhuis, A.A., Picchioni, F.: Polymeric surfactants for enhanced oil recovery: a review. J. Pet. Sci. Eng. 145, 723733 (2016). https://doi.org/10.1016/j.petrol.2016.07.007

33. Cheraghian, G., Hendraningrat, L.: A review on applications of nanotechnology in the enhanced oil recovery part A: effects of nanoparticles on interfacial tension. Int. Nano Lett. 6, 129-138 (2016). https://doi.org/10.1007/s40089-015-0173-4

34. Liu, Q., Dong, M., Ma, S., Tu, Y.: Surfactant enhanced alkaline flooding for Western Canadian heavy oil recovery. Colloids Surf. A Physicochem. Eng. Asp 293, 63-71 (2007). https://doi. org/10.1016/j.colsurfa.2006.07.013

35. Bashir, A., Sharifi Haddad, A., Rafati, R.: Experimental investigation of nanoparticles/polymer enhanced $\mathrm{CO}_{2}$-foam in the presence of hydrocarbon at high-temperature conditions. In: SPE Int. Heavy Oil Conf. Exhib. 10-12 December, pp. 1-13. Society of Petroleum Engineers, Kuwait City (2018). https://doi. org/10.2118/193802-ms

36. Mandal, A.: Chemical flood enhanced oil recovery: a review. Int. J Oil Gas Coal Technol. 9, 241-264 (2015)

37. Mandal, A., Samanta, A., Ojha, K.: Mobility control and enhanced oil recovery using partially hydrolysed polyacrylamide (PHPA). Int. J. Oil Gas Coal Technol. 6, 245-258 (2013). https ://doi.org/10.1504/IJOGCT.2013.052236

38. Wei, B.: Advances in polymer flooding. In: El-Amin, M.F. (ed.) Viscoelastic and Viscoplastic Materials. IntechOpen. https://doi. org/10.5772/64069. https://www.intechopen.com/books/visco elastic-and-viscoplastic-materials/advances-in-polymer-flooding

39. Sheng, J.J.: Polymer flooding-fundamentals and field cases. Enhanc. Oil Recover. F. Case Stud. (2013). https://doi. org/10.1016/b978-0-12-386545-8.00003-8

40. Delshad, M., Kim, D.H., Magbagbeola, O.A., Huh, C., Pope, G.A., Tarahhom, F.: Mechanistic interpretation and utilization of viscoelastic behavior of polymer solutions for improved polymerflood efficiency. In: Present. SPE Symp. Improv. Oil Recover. 20-23 April. Tulsa, Oklahoma, USA, Society of Petroleum Engineers, pp. 1-15 (2008). https://doi.org/10.2118/113620-ms

41. Mishra, S., Bera, A., Mandal, A., Mishra, S., Bera, A., Mandal, A.: Effect of polymer adsorption on permeability reduction in enhanced oil recovery. J. Pet. Eng. 2014, 1-9 (2014). https://doi. org/10.1155/2014/395857
42. Wei, B., Romero-Zerón, L., Rodrigue, D.: Oil displacement mechanisms of viscoelastic polymers in enhanced oil recovery (EOR): a review. J. Pet. Explor. Prod. Technol. 4, 113-121 (2014). https://doi.org/10.1007/s13202-013-0087-5

43. Veerabhadrappa, S.K., Trivedi, J.J., Kuru, E.: Visual confirmation of the elasticity dependence of unstable secondary polymer floods. Ind. Eng. Chem. Res. 52, 6234-6241 (2013). https://doi. org/10.1021/ie303241b

44. Urbissinova, T.S., Trivedi, J., Kuru, E.: Effect of elasticity during viscoelastic polymer flooding: a possible mechanism of increasing the sweep efficiency. SPE-133471-PA. J. Can. Pet. Technol. 49, 49-56 (2010). https://doi.org/10.2118/133471-pa

45. Veerabhadrappa, S.K.: Study of effects of polymer elasticity on enhanced oil recovery by core flooding and visualization experiments (thesis). A Master's thesis submitted to the Department of Civil and Environmental Engineering, University of Alberta (2013)

46. Taylor, K.C., Nasr-El-Din, H.A.: Water-soluble hydrophobically associating polymers for improved oil recovery: a literature review. J. Pet. Sci. Eng. 19, 265-280 (1998). https://doi. org/10.1016/S0920-4105(97)00048-X

47. Kamal, M.S., Sultan, A.S., Al-Mubaiyedh, U.A., Hussein, I.A.: Review on polymer flooding: rheology, adsorption, stability, and field applications of various polymer systems. Polym. Rev. 55, 491-530 (2015). https://doi.org/10.1080/15583724.2014.98282 1

48. Pu, W., Shen, C., Wei, B., Yang, Y., Li, Y.: A comprehensive review of polysaccharide biopolymers for enhanced oil recovery (EOR) from flask to field. J. Ind. Eng. Chem. 61, 1-11 (2018). https://doi.org/10.1016/j.jiec.2017.12.034

49. Wever, D.A.Z., Picchioni, F., Broekhuis, A.A.: Polymers for enhanced oil recovery: a paradigm for structure-property relationship in aqueous solution. Prog. Polym. Sci. 36, 1558-1628 (2011). https://doi.org/10.1016/j.progpolymsci.2011.05.006

50. Gao, C.: Viscosity of partially hydrolyzed polyacrylamide under shearing and heat. J. Pet. Explor. Prod. Technol. 3, 203-206 (2013). https://doi.org/10.1007/s13202-013-0051-4

51. Chauveteau, G., Zaitoun, A.: basic rheological behavior of xanthan polysaccharide solutions in porous media: effect of pore size and polymer concentration. In: Proceedings of the First European Symposium on Enhanced Oil Recovery, Bournemouth, England, Soc. Pet. Eng. Richardson, TX, pp. 197-212 (1981)

52. Needham, R.B., Doe, P.H.: Polymer flooding review. J. Pet. Technol. 39, 1503-1507 (1987). https://doi.org/10.2118/17140-PA

53. Kennedy, J.R.M., Kent, K.E., Brown, J.R.: Rheology of dispersions of xanthan gum, locust bean gum and mixed biopolymer gel with silicon dioxide nanoparticles. Mater. Sci. Eng., C 48, 347-353 (2015). https://doi.org/10.1016/j.msec.2014.12.040

54. Sheng, J.J.: Chapter 5-polymer flooding. Mod. Chem. Enhanc. Oil Recover. 5, 101-206 (2011). https://doi.org/10.1016/b978-185617-745-0.00005-x

55. Choppe, E., Puaud, F., Nicolai, T., Benyahia, L.: Rheology of xanthan solutions as a function of temperature, concentration and ionic strength. Carbohydr. Polym. 82, 1228-1235 (2010). https ://doi.org/10.1016/j.carbpol.2010.06.056

56. Xin, X., Yu, G., Chen, Z., Wu, K., Dong, X., Zhu, Z.: Effect of polymer degradation on polymer flooding in heterogeneous reservoirs. Polymers (Basel) 10, 1-25 (2018). https://doi. org/10.3390/polym 10080857

57. Agi, A., Junin, R., Gbonhinbor, J., Onyekonwu, M.: Natural polymer flow behaviour in porous media for enhanced oil recovery applications: a review. J. Pet. Explor. Prod. Technol. (2018). https ://doi.org/10.1007/s13202-018-0434-7

58. Abbas, A.H., Sulaiman, W.R.W., Jaafar, M.Z., Gbadamosi, A.O., Ebrahimi, S.S., Elrufai, A.: Numerical study for continuous 
surfactant flooding considering adsorption in heterogeneous reservoir. J. King. Saud. Univ. Eng. Sci. 5, 1-9 (2018). https:// doi.org/10.1016/j.jksues.2018.06.001

59. Negin, C., Ali, S., Xie, Q.: Most common surfactants employed in chemical enhanced oil recovery. Petroleum 3, 197-211 (2017). https://doi.org/10.1016/j.petlm.2016.11.007

60. Cheraghian, G.: Effects of nanoparticles on wettability: a review on applications of nanotechnology in the enhanced oil recovery. Int. J Nano Dimens. 6, 443-452 (2015). https://doi.org/10.7508/ ijnd.2015.05.001

61. Mohammed, M., Babadagli, T.: Wettability alteration: a comprehensive review of materials/methods and testing the selected ones on heavy-oil containing oil-wet systems. Adv. Colloid Interface Sci. 220, 54-77 (2015). https://doi.org/10.1016/j.cis.2015.02.006

62. Alhammadi, A.M., AlRatrout, A., Singh, K., Bijeljic, B., Blunt, M.J.: In situ characterization of mixed-wettability in a reservoir rock at subsurface conditions. Sci. Rep. 7, 10753 (2017). https:// doi.org/10.1038/s41598-017-10992-w

63. Christensen, M., Tanino, Y.: Waterflood oil recovery from mixedwet limestone: dependence upon the contact angle. Energy Fuels 31, 1529-1535 (2017). https://doi.org/10.1021/acs.energyfuel s.6b03249

64. Alvarez, J.O., Schechter, D.S.: Wettability alteration and spontaneous imbibition in unconventional liquid reservoirs by surfactant additives. SPE J. 20, 107-117 (2017). https://doi. org/10.2118/177057-PA

65. Mirchi, V., Saraji, S., Goual, L., Piri, M.: Dynamic interfacial tension and wettability of shale in the presence of surfactants at reservoir conditions. Fuel 148, 127-138 (2015). https://doi. org/10.1016/j.fuel.2015.01.077

66. Kathel, P., Mohanty, K.K.: Wettability alteration in a tight oil reservoir. Energy Fuels 27, 6460-6468 (2013). https://doi. org/10.1021/ef4012752

67. Jarrahian, K., Seiedi, O., Sheykhan, M., Sefti, M.V., Ayatollahi, S.: Wettability alteration of carbonate rocks by surfactants: a mechanistic study. Colloids. Surf. A Physicochem. Eng. Asp 410, 1-10 (2012). https://doi.org/10.1016/j.colsurfa.2012.06.007

68. Salehi, M., Johnson, S.J., Liang, J.-T.: Mechanistic study of wettability alteration using surfactants with applications in naturally fractured reservoirs. Langmuir 24, 14099-14107 (2008). https:// doi.org/10.1021/la802464u

69. Salehi, M., Johnson, S.J., Liang, J.-T.: Enhanced wettability alteration by surfactants with multiple hydrophilic moieties. J. Surf. Deterg. 13, 243-246 (2010). https://doi.org/10.1007/s1174 3-010-1193-8

70. Esmaeilzadeh, P., Bahramian, A., Fakhroueian, Z.: Adsorption of anionic, cationic and nonionic surfactants on carbonate rock in presence of $\mathrm{ZrO}_{2}$ nanoparticles. Phys. Proc. 22, 63-67 (2011). https://doi.org/10.1016/j.phpro.2011.11.009

71. Standnes, D.C., Austad, T.: Wettability alteration in carbonates: interaction between cationic surfactant and carboxylates as a key factor in wettability alteration from oil-wet to water-wet conditions. Colloids Surf. A Physicochem. Eng. Asp 216, 243-259 (2003). https://doi.org/10.1016/S0927-7757(02)00580-0

72. Strand, S., Standnes, D.C., Austad, T.: Spontaneous imbibition of aqueous surfactant solutions into neutral to oil-wet carbonate cores: effects of brine salinity and composition. Energy Fuels 17, 1133-1144 (2003). https://doi.org/10.1021/ef030051s

73. Standnes, D.C., Nogaret, L.A.D., Chen, H.-L., Austad, T.: An evaluation of spontaneous imbibition of water into oil-wet carbonate reservoir cores using a nonionic and a cationic surfactant. Energy Fuels 16, 1557-1564 (2002). https://doi.org/10.1021/ ef0201127

74. Hou, B., Wang, Y., Huang, Y.: Mechanistic study of wettability alteration of oil-wet sandstone surface using different surfactants.
Appl. Surf. Sci. 330, 56-64 (2015). https://doi.org/10.1016/j. apsusc.2014.12.185

75. Hou, B., Wang, Y., Cao, X., Zhang, J., Song, X., Ding, M., et al.: Surfactant-induced wettability alteration of oil-wet sandstone surface: mechanisms and its effect on oil recovery. J. Surf. Deterg. 19, 315-324 (2016). https://doi.org/10.1007/s1174 3-015-1770-y

76. Pal, S., Mushtaq, M., Banat, F., Al Sumaiti, A.M.: Review of surfactant-assisted chemical enhanced oil recovery for carbonate reservoirs: challenges and future perspectives. Pet. Sci. $\mathbf{1 5}$, 77-102 (2018). https://doi.org/10.1007/s12182-017-0198-6

77. Kumar, S., Panigrahi, P., Saw, R.K., Mandal, A.: Interfacial interaction of cationic surfactants and its effect on wettability alteration of oil-wet carbonate rock. Energy Fuels 30, 2846-2857 (2016). https://doi.org/10.1021/acs.energyfuels.6b00152

78. Ahmadi, M.A., Zendehboudi, S., Shafiei, A., James, L.: Nonionic surfactant for enhanced oil recovery from carbonates: adsorption kinetics and equilibrium. Ind. Eng. Chem. Res. 51, 9894-9905 (2012). https://doi.org/10.1021/ie300269c

79. Kumar, A., Mandal, A.: Synthesis and physiochemical characterization of zwitterionic surfactant for application in enhanced oil recovery. J. Mol. Liq. 243, 61-71 (2017). https://doi. org/10.1016/j.molliq.2017.08.032

80. Amirianshoja, T., Junin, R., Idris, A.K., Rahmani, O.: A comparative study of surfactant adsorption by clay minerals. J. Pet. Sci. Eng. 101, 21-27 (2013). https://doi.org/10.1016/j.petro 1.2012.10.002

81. Muherei, M.A., Junin, R., Merdhah, A.B.: Adsorption of sodium dodecyl sulfate, Triton X100 and their mixtures to shale and sandstone: a comparative study. J. Pet. Sci. Eng. 67, 149-154 (2009). https://doi.org/10.1016/j.petrol.2009.05.006

82. Yekeen, N., Manan, M.A., Idris, A.K., Samin, A.M.: Influence of surfactant and electrolyte concentrations on surfactant Adsorption and foaming characteristics. J. Pet. Sci. Eng. 149, 612-622 (2017). https://doi.org/10.1016/j.petrol.2016.11.018

83. ShamsiJazeyi, H., Verduzco, R., Hirasaki, G.J.: Reducing adsorption of anionic surfactant for enhanced oil recovery: Part I. Competitive adsorption mechanism. Colloids Surf. A Physicochem. Eng. Asp 453, 162-167 (2014). https://doi. org/10.1016/j.colsurfa.2013.10.042

84. Gong, H., Li, Y., Dong, M., Ma, S., Liu, W.: Effect of wettability alteration on enhanced heavy oil recovery by alkaline flooding. Colloids Surf. A Physicochem. Eng. Asp 488, 28-35 (2016). https://doi.org/10.1016/j.colsurfa.2015.09.042

85. Pei, H., Zhang, G., Ge, J., Jin, L., Ma, C.: Potential of alkaline flooding to enhance heavy oil recovery through waterin-oil emulsification. Fuel 104, 284-293 (2013). https://doi. org/10.1016/j.fuel.2012.08.024

86. Sheng, J.J.: A comprehensive review of alkaline-surfactantpolymer (ASP) flooding. Asia Pac. J. Chem. Eng. 9, 471-489 (2014). https://doi.org/10.1002/apj

87. Sydansk, R.D.: Elevated-temperature caustic/sandstone interaction: implications for improving oil recovery (includes associated papers 11348 and 11548). Soc. Pet. Eng. J. 22, 453-462 (1982). https://doi.org/10.2118/9810-PA

88. Zhang, J., Nguyen, Q.P., Flaaten, A., Pope, G.A.: Mechanisms of enhanced natural imbibition with novel chemicals. Soc. Pet. Eng. J. 12, 912-920 (2009). https://doi.org/10.2118/11345 3-PA

89. Yekeen, N., Idris, A.K., Manan, M., Samin, A.M., Risal, A.R., Kun, T.X.: Bulk and bubble-scale experimental studies of influence of nanoparticles on foam stability. Chin. J. Chem. Eng. 25, 347-357 (2017). https://doi.org/10.1016/j.cjche.2016.08.012

90. Rafati, R., Haddad, A.S., Hamidi, H.: Experimental study on stability and rheological properties of aqueous foam in the presence of reservoir natural solid particles. Colloids Surf. 
A Physicochem. Eng. Asp 509, 19-31 (2016). https://doi. org/10.1016/j.colsurfa.2016.08.087

91. Rafati, R., Oludara, O.K., Haddad, A.S., Hamidi, H.: Experimental investigation of emulsified oil dispersion on bulk foam stability. Colloids Surf. A Physicochem. Eng. Asp 554, 110-121 (2018). https://doi.org/10.1016/j.colsurfa.2018.06.043

92. Ahmadi, M.A., Shadizadeh, S.R., Salari, Z.: Dependency of critical micellization concentration of an anionic surfactant on temperature and potassium chloride salt. Pet. Sci. Technol. 32, 19131920 (2014). https://doi.org/10.1080/10916466.2011.653700

93. Rossen, W.R.: A critical review of Roof snap-off as a mechanism of steady-state foam generation in homogeneous porous media. Colloids Surf. A Physicochem. Eng. Asp 225, 1-24 (2003). https ://doi.org/10.1016/S0927-7757(03)00309-1

94. Singh, R., Mohanty, K.K.: Synergy between nanoparticles and surfactants in stabilizing foams for oil recovery. Energy Fuels 29, 467-479 (2015). https://doi.org/10.1021/ef5015007

95. Zhu, T., Ogbe, D.O., Khataniar, S.: Improving the foam performance for mobility control and improved sweep efficiency in gas flooding. Ind. Eng. Chem. Res. 43, 4413-4421 (2004). https:// doi.org/10.1021/ie034021o

96. Yusuf, S.M., Manan, M.A., Jaafar, M.Z.: Aqueous foams stabilized by hydrophilic silica nanoparticles via in-situ physisorption of nonionic TX100 surfactant. Iran. J. Energy Environ. 4(1), 8-16 (2013). https://doi.org/10.5829/idosi.ijee.2013.04.01.41132

97. Krzan, M., Caps, H., Vandewalle, N.: High stability of the bovine serum albumin foams evidenced in Hele-Shaw cell. Colloids Surf. A Physicochem. Eng. Asp 438, 112-118 (2013). https:// doi.org/10.1016/j.colsurfa.2013.01.012

98. Fameau, A.-L., Salonen, A.: Effect of particles and aggregated structures on the foam stability and aging. Comptes. Rendus. Phys. 15, 748-760 (2014). https://doi.org/10.1016/j. crhy.2014.09.009

99. Hirasaki, G., Miller, C.A., Puerto, M.: Recent advances in surfactant EOR. Soc. Pet. Eng. J. 16, 889-907 (2011). https://doi. org/10.2118/115386-pa

100. Sheng, J.J.: Critical review of alkaline-polymer flooding. J. Pet. Explor. Prod. Technol. 7, 147-153 (2017). https://doi. org/10.1007/s13202-016-0239-5

101. Chul, J.J., Ke, Z., Hyun, C.B., Jin, C.H.: Rheology and polymer flooding characteristics of partially hydrolyzed polyacrylamide for enhanced heavy oil recovery. J. Appl. Polym. Sci. 127, 48334839 (2012). https://doi.org/10.1002/app.38070

102. Samanta, A., Ojha, K., Sarkar, A., Mandal, A.: Surfactant and surfactant-polymer flooding for enhanced oil recovery. Adv. Pet. Explor. Dev. 2, 13-18 (2011)

103. Pogaku, R., Mohd Fuat, N.H., Sakar, S., Cha, Z.W., Musa, N., Awang Tajudin, D.N.A., et al.: Polymer flooding and its combinations with other chemical injection methods in enhanced oil recovery. Polym. Bull. 74, 1-22 (2017). https://doi.org/10.1007/ s00289-017-2106-Z

104. Dang, C., Nghiem, L., Nguyen, N., Yang, C., Chen, Z., Bae, W.: Modeling and optimization of alkaline-surfactant-polymer flooding and hybrid enhanced oil recovery processes. J. Pet. Sci. Eng. 169, 578-601 (2018). https://doi.org/10.1016/j.petro 1.2018.06.017

105. Pal, N., Saxena, N., Mandal, A.: Characterization of alkalisurfactant-polymer slugs using synthesized gemini surfactant for potential application in enhanced oil recovery. J. Pet. Sci. Eng. 168, 283-300 (2018). https://doi.org/10.1016/j.petro 1.2018.05.026

106. Qing, J., Zhou, B., Zhang, R., Chen, Z., Zhou, Y.: Development and application of a silicate scale inhibitor for asp flooding production scale. In: International Symposium Oilf. Scale, 30-31 January, Aberdeen, United Kingdom, Society of Petroleum Engineers, pp. 1-4 (2002). https://doi.org/10.2118/74675-ms
107. Nguyen, D.T., Sadeghi, N.: Stable emulsion and demulsification in chemical EOR flooding: challenges and best practices. In: SPE EOR Conf Oil Gas West Asia, 16-18 April Muscat, Oman (2012). https://doi.org/10.2118/154044-ms

108. Fakoya, M.F., Shah, S.N.: Emergence of nanotechnology in the oil and gas industry: emphasis on the application of silica nanoparticles. Petroleum (2017). https://doi.org/10.1016/j.petlm 2017.03.001

109. Almahfood, M., Bai, B.: The synergistic effects of nanoparticlesurfactant nanofluids in EOR applications. J. Pet. Sci. Eng. 171, 196-210 (2018). https://doi.org/10.1016/j.petrol.2018.07.030

110. Mahsa, B.S.: Enhancing hydrocarbon productivity via wettability alteration: a review on the application of nanoparticles. Rev. Chem. Eng. (2018). https://doi.org/10.1515/revce-2017-0105

111. Wasan, D.T., Nikolov, A.D.: Spreading of nanofluids on solids. Nature 423, 156-159 (2003)

112. Kondiparty, K., Nikolov, A., Wu, S., Wasan, D.: Wetting and spreading of nanofluids on solid surfaces driven by the structural disjoining pressure: statics analysis and experiments. Langmuir 27, 3324-3335 (2011). https://doi.org/10.1021/la104204b

113. Mcelfresh, P.M., Holcomb, D.L., Ector, D.: Application of nanofluid technology to improve recovery in oil and gas wells. In: SPE Int. Oilf. Nanotechnol. Conf. Exhib., Noordwijk, The Netherlands: Society of Petroleum Engineers, pp. 1-6 (2012). https:// doi.org/10.2118/154827-ms

114. Wasan, D., Nikolov, A., Kondiparty, K.: The wetting and spreading of nanofluids on solids: role of the structural disjoining pressure. Curr. Opin. Colloid Interface Sci. 16, 344-349 (2011). https ://doi.org/10.1016/j.cocis.2011.02.001

115. Onyekonwu, M.O., Ogolo, N.A.: Investigating the use of nanoparticles in enhancing oil recovery. In: Niger. Annu. Int. Conf. Exhib. 31 July-7 August, Tinapa, Calabar, Niger. Society of Petroleum Engineers, pp. 1-14 (2010). https://doi. org/10.2118/140744-ms

116. Hendraningrat, L., Li, S., Torsæter, O.: A coreflood investigation of nanofluid enhanced oil recovery. J. Pet. Sci. Eng. 111, 128-138 (2013). https://doi.org/10.1016/j.petrol.2013.07.003

117. Torsater, O., Engeset, B., Hendraningrat, L., Suwarno, S.: Improved oil recovery by nanofluids flooding: an experimental study. In: Present. SPE Kuwait Int. Pet. Conf. Exhib. 10-12 December, Kuwait City, Kuwait, Society of Petroleum Engineers, pp. 1-9 (2012). https://doi.org/10.2118/163335-ms

118. Roustaei, A., Moghadasi, J., Bagherzadeh, H., Shahrabadi, A.: An experimental investigation of polysilicon nanoparticles' recovery efficiencies through changes in interfacial tension and wettability alteration. In: Present. SPE Int. Oilf. Nanotechnol. Conf. Exhib. 12-14 June, Noordwijk, The Netherlands, Society of Petroleum Engineers, pp. 1-7 (2012). https://doi. org/10.2118/156976-ms

119. Li, S., Torsæter, O.: An experimental investigation of EOR mechanisms for nanoparticles fluid in glass micromodel. In: Int. Symp. Soc. Core Anal. (Avignon/Fr.), pp. 1-12 (2014). https:// doi.org/10.13140/rg.2.1.4181.3604

120. Chevalier, Y., Bolzinger, M.-A.: Emulsions stabilized with solid nanoparticles: pickering emulsions. Colloids Surf. A Physicochem. Eng. Asp 439, 23-34 (2013). https://doi.org/10.1016/j. colsurfa.2013.02.054

121. Kumar, S., Ray, D., Aswal, V.K., Kohlbrecher, J.: Structure and interaction in the polymer-dependent reentrant phase behavior of a charged nanoparticle solution. Phys. Rev. E. Stat. Nonlinear Soft Matter Phys 90, 1-10 (2014). https://doi.org/10.1103/PhysR evE.90.042316

122. Hu, Z., Haruna, M., Gao, H., Nourafkan, E., Wen, D.: Rheological properties of partially hydrolyzed polyacrylamide seeded by nanoparticles. Ind. Eng. Chem. Res. 56, 3456-3463 (2017). https ://doi.org/10.1021/acs.iecr.6b05036 
123. Maghzi, A., Kharrat, R., Mohebbi, A., Ghazanfari, M.H.: The impact of silica nanoparticles on the performance of polymer solution in presence of salts in polymer flooding for heavy oil recovery. Fuel 123, 123-132 (2014). https://doi.org/10.1016/j. fuel.2014.01.017

124. Mallakpour, S., Khadem, E.: Recent development in the synthesis of polymer nanocomposites based on nano-alumina. Prog. Polym. Sci. 51, 74-93 (2015). https://doi.org/10.1016/j.progp olymsci.2015.07.004

125. ShamsiJazeyi, H., Miller, C.A., Wong, M.S., Tour, J.M., Verduzco, R.: Polymer-coated nanoparticles for enhanced oil recovery. J. Appl. Polym. Sci. 131, 1-13 (2014). https://doi. org/10.1002/app.40576

126. Wu, Y., Chen, W., Dai, C., Huang, Y., Li, H., Zhao, M., et al.: Reducing surfactant adsorption on rock by silica nanoparticles for enhanced oil recovery. J. Pet. Sci. Eng. 153, 283-287 (2017). https://doi.org/10.1016/j.petrol.2017.04.015

127. Suresh, R., Kuznetsov, O., Agrawal, D., Darugar, Q., Khabashesku, V.: Reduction of surfactant adsorption in porous media using silica nanoparticles. In: Present. Offshore Technol. Conf. 30 April-3 May, Houston, Texas, USA, pp. 1-9 (2018)

128. Farajzadeh, R., Andrianov, A., Krastev, R., Hirasaki, G., Rossen, W.R.: Foam-oil interaction in porous media: implications for foam assisted enhanced oil recovery. In: SPE EOR Conf. Oil Gas West Asia, 16-18 April. Muscat, Oman, Muscat, Oman: Society of Petroleum Engineers, pp. 1-20 (2012). https://doi. org/10.2118/154197-ms

129. Nwidee, L.N., Lebedev, M., Barifcani, A., Sarmadivaleh, M., Iglauer, S.: Wettability alteration of oil-wet limestone using surfactant-nanoparticle formulation. J. Colloid Interface Sci. 504, 334-345 (2017). https://doi.org/10.1016/j.jcis.2017.04.078

130. Zhang, T., Roberts, M., Bryant, S.L., Huh, C.: Foams and emulsions stabilized with nanoparticles for potential conformance control applications. In: Present. SPE Int. Symp. Oilf. Chem. 20-22 April. Woodlands. Texas, Society of Petroleum Engineers, pp. 1-17 (2009). https://doi.org/10.2118/121744-ms

131. Mohd, T.A.T., Shukor, M.A.A., Ghazali, N.A., Alias, N., Yahya, E., Azizi, A., et al.: Relationship between foamability and nanoparticle concentration of carbon dioxide $\left(\mathrm{CO}_{2}\right)$ foam for enhanced oil recovery (EOR). Appl. Mech. Mater. 548-549, 67-71 (2014). https://doi.org/10.4028/www.scientific.net/AMM.548-549.67

132. Binks, B.P., Horozov, T.S.: Aqueous foams stabilized solely by silica nanoparticles. Angew. Chem. Int. Ed. 44, 3722-3725 (2005). https://doi.org/10.1002/anie.200462470

133. Zhang, S., Lan, Q., Liu, Q., Xu, J., Sun, D.: Aqueous foams stabilized by laponite and CTAB. Colloids Surf. A Physicochem. Eng. Asp 317, 406-413 (2008). https://doi.org/10.1016/j.colsu rfa.2007.11.010

134. Sun, Q., Li, Z., Li, S., Jiang, L., Wang, J., Wang, P.: Utilization of surfactant-stabilized foam for enhanced oil recovery by adding nanoparticles. Energy Fuels 28, 2384-2394 (2014). https://doi. org/10.1021/ef402453b

135. Binks, B.P.: Particles as surfactants—similarities and differences. Curr. Opin. Colloid Interface Sci. 7, 21-41 (2002). https://doi. org/10.1016/S1359-0294(02)00008-0

136. Worthen, A., Bagaria, H., Chen, Y., Bryant, S.L., Huh, C., Johnston, K.P.: Nanoparticle stabilized carbon dioxide in water foams for enhanced oil recovery. In: Present. SPE Improv. Oil Recover. Symp. 14-18 April. Tulsa, Oklahoma, USA, Tulsa, Oklahoma, USA: Society of Petroleum Engineers, pp. 1-7 (2012). https:// doi.org/10.2118/154285-ms

137. Heydarian, A., Kharrat, R., Heydarian, S., Hashemi, A.: Impact of nano-particles on static performance of surfactant foams. J Am Sci 9, 444-449 (2013)

138. Afolabi, R.O.: Enhanced oil recovery for emergent energy demand: challenges and prospects for a nanotechnology paradigm shift. Int. Nano. Lett. (2018). https://doi.org/10.1007/ s40089-018-0248-0

139. He, Z., Alexandridis, P.: Ionic liquid and nanoparticle hybrid systems: emerging applications. Adv. Colloid Interface Sci. 244, 54-70 (2017). https://doi.org/10.1016/j.cis.2016.08.004

140. Chen, S.-L., Chua, G.-L., Ji, S.-J., Loh, T.-P.: Ionic liquid: a green solvent for organic transformations II. Ion. Liq. Org. Synth. (2007). https://doi.org/10.1021/bk-2007-0950.ch014

141. Mohammed, M.A., Babadagli, T.: Experimental investigation of wettability alteration in oil-wet reservoirs containing heavy oil. SPE Reserv. Eval. Eng. 19, 633-644 (2016). https://doi. org/10.2118/170034-PA

142. Bera, A., Belhaj, H.: Ionic liquids as alternatives of surfactants in enhanced oil recovery-a state-of-the-art review. J. Mol. Liq. 224, 177-188 (2016). https://doi.org/10.1016/j.molli q.2016.09.105

143. Hezave, A.Z., Dorostkar, S., Ayatollahi, S., Nabipour, M., Hemmateenejad, B.: Dynamic interfacial tension behavior between heavy crude oil and ionic liquid solution (1-dodecyl-3-methylimidazolium chloride $\left([\mathrm{C} 12 \mathrm{mim}][\mathrm{Cl}]^{+}\right.$distilled or saline water/ heavy crude oil)) as a new surfactant. J. Mol. Liq. 187, 83-89 (2013). https://doi.org/10.1016/j.molliq.2013.05.007

144. Hezave, A.Z., Dorostkar, S., Ayatollahi, S., Nabipour, M., Hemmateenejad, B.: Effect of different families (imidazolium and pyridinium) of ionic liquids-based surfactants on interfacial tension of water/crude oil system. Fluid Phase Equilib. 360, 139-145 (2013). https://doi.org/10.1016/j.fluid .2013 .09 .025

145. Pillai, P., Kumar, A., Mandal, A.: Mechanistic studies of enhanced oil recovery by imidazolium-based ionic liquids as novel surfactants. J. Ind. Eng. Chem. 63, 262-274 (2018). https ://doi.org/10.1016/j.jiec.2018.02.024

146. Bin Dahbag, M., AlQuraishi, A., Benzagouta, M.: Efficiency of ionic liquids for chemical enhanced oil recovery. J. Pet. Explor. Prod. Technol. 5, 353-361 (2015). https://doi.org/10.1007/s1320 2-014-0147-5

147. Aitkulov, A., Luo, H., Lu, J., Mohanty, K.K.: Alkali-cosolventpolymer flooding for viscous oil recovery: $2 \mathrm{D}$ evaluation. Energy Fuels 31, 7015-7025 (2017). https://doi.org/10.1021/acs.energ yfuels.7b00790

148. Fortenberry, R., Kim, D.H., Nizamidin, N., Adkins, S., Arachchilage, G.W.P.P., Koh, H.S., et al.: Use of cosolvents to improve alkaline/polymer flooding. SPE J. 20, 255-266 (2015). https:// doi.org/10.2118/166478-PA

149. Yuan, B., Wood, D.A.: Chapter one-overview of formation damage during improved and enhanced oil recovery. In: Yuan, B., Wood, D.A. (eds.) Form Damage Dur Improv Oil Recover, pp. 1-20. Gulf Professional Publishing, Houston (2018). https:// doi.org/10.1016/B978-0-12-813782-6.00001-4

150. Yuan, B., Wood, D.A.: A comprehensive review of formation damage during enhanced oil recovery. J. Pet. Sci. Eng. 167, 287-299 (2018). https://doi.org/10.1016/j.petrol.2018.04.018

151. Civan, F.: Chapter 1 -overview of formation damage. In: Civan, F. (ed.) Reserv Form Damage, 3rd edn, pp. 1-6. Gulf Professional Publishing, Boston (2016). https://doi.org/10.1016/B9780-12-801898-9.00001-1

152. Dai, C.: Chapter seven-formation damage during chemical flooding. In: Yuan, B., Wood, D.A. (eds.) Form Damage Dur Improv Oil Recover, pp. 275-304. Gulf Professional Publishing, Boston (2018). https://doi.org/10.1016/B978-0-12-81378 2-6.00007-5

153. Guo, H., Li, Y., Wang, F., Yu, Z., Chen, Z., Wang, Y., et al.: ASP flooding: theory and practice progress in China. J Chem (2017). https://doi.org/10.1155/2017/8509563 
154. Kalfoglou, G.: Lignosulfonates as sacrificial agents in oil recovery processes. US Patent No. 4006779. https://www.osti.gov/ biblio/7119809 (1977)

155. Novosad, J.: Laboratory evaluation of lignosulfonates as sacrificial adsorbates in surfactant flooding. J. Can. Pet. Technol. 23, 1-6 (1984). https://doi.org/10.2118/84-03-01

156. Algharaib, M., Alajmi, A., Gharbi, R.: Improving polymer flood performance in high salinity reservoirs. J. Pet. Sci. Eng. 115, 17-23 (2014). https://doi.org/10.1016/j.petrol.2014.02.003

157. Algharaib, M.K., Abedi, M.A.: Optimization of polymer flood performance by preflush injection-numerical investigation. In: SPE Kuwait Int Pet Conf Exhib 10-12 December, Kuwait City, Kuwait, pp. 1-14 (2012). https://doi.org/10.2118/163280-ms

158. Kumar, S., Saxena, N., Mandal, A.: Synthesis and evaluation of physicochemical properties of anionic polymeric surfactant derived from Jatropha oil for application in enhanced oil recovery. J. Ind. Eng. Chem. 43, 106-116 (2016). https://doi. org/10.1016/j.jiec.2016.07.055

159. Zhang, Q.-Q., Cai, B.-X., Xu, W.-J., Gang, H.-Z., Liu, J.-F., Yang, S.-Z., et al.: The rebirth of waste cooking oil to novel biobased surfactants. Sci. Rep. 5, 9971 (2015)

160. Eftekhari, A.A., Krastev, R., Farajzadeh, R.: Foam stabilized by fly ash nanoparticles for enhancing oil recovery. Ind. Eng. Chem. Res. 54, 12482-12491 (2015). https://doi.org/10.1021/ acs.iecr.5b03955

161. Ponnapati, R., Karazincir, O., Dao, E., Ng, R., Mohanty, K.K., Krishnamoorti, R.: Polymer-functionalized nanoparticles for improving waterflood sweep efficiency: characterization and transport properties. Ind. Eng. Chem. Res. 50, 13030-13036 (2011). https://doi.org/10.1021/ie2019257

162. Pu, W.-F., Liu, R., Wang, K.-Y., Li, K.-X., Yan, Z.-P., Li, B., et al.: Water-soluble core-shell hyperbranched polymers for enhanced oil recovery. Ind. Eng. Chem. Res. 54, 798-807 (2015). https://doi.org/10.1021/ie5039693

163. Maurya, N.K., Kushwaha, P., Mandal, A.: Studies on interfacial and rheological properties of water soluble polymer grafted nanoparticle for application in enhanced oil recovery. J. Taiwan Inst. Chem. Eng. 70, 319-330 (2017). https://doi. org/10.1016/j.jtice.2016.10.021

164. Cheng, Y., Zhao, M., Zheng, C., Guo, S., Li, X., Zhang, Z.: Water-dispersible reactive nanosilica and poly(2-acrylamido2-methyl-1-propanesulfonic acid sodium) nanohybrid as potential oil displacement agent for enhanced oil recovery. Energy Fuels 31, 6345-6351 (2017). https://doi.org/10.1021/acs.energ yfuels.7b00743

165. Behzadi, A., Mohammadi, A.: Environmentally responsive surface-modified silica nanoparticles for enhanced oil recovery. J Nanoparticle Res 18, 1-19 (2016). https://doi.org/10.1007/ s11051-016-3580-1

166. Liu, R., Pu, W., Sheng, J.J., Du, D.: Star-like hydrophobically associative polyacrylamide for enhanced oil recovery: comprehensive properties in harsh reservoir conditions. J. Taiwan. Inst. Chem. Eng. 80, 639-649 (2017). https://doi.org/10.1016/j. jtice.2017.08.043

167. Liu, R., Pu, W.-F., Du, D.-J.: Synthesis and characterization of core-shell associative polymer that prepared by oilfield formation water for chemical flooding. J. Ind. Eng. Chem. 46, 80-90 (2017). https://doi.org/10.1016/j.jiec.2016.10.018

168. Ye, Z., Qin, X., Lai, N., Peng, Q., Li, X., Li, C.: Synthesis and performance of an acrylamide copolymer containing nano$\mathrm{SiO} 2$ as enhanced oil recovery chemical. J Chem 2013, 1-33 (2013)

169. Yang-Chuan, K., Guang-Yao, W., Yi, W.: Preparation, morphology and properties of nanocomposites of polyacrylamide copolymers with monodisperse silica. Eur. Polym. J. 44, 2448-2457 (2008). https://doi.org/10.1016/j.eurpolymj.2008.06.007
170. Lai, N., Wu, T., Ye, Z., Zhang, Y., Zhou, N., Zeng, F.: Hybrid hyperbranched polymer based on modified nano-SiO $\mathrm{Si}_{2}$ for enhanced oil recovery. Chem. Lett. 45, 1189-1191 (2016). https ://doi.org/10.1246/cl.160554

171. Maghzi, A., Mohebbi, A., Kharrat, R., Ghazanfari, M.H.: Porescale monitoring of wettability alteration by silica nanoparticles during polymer flooding to heavy oil in a five-spot glass micromodel. Transp. Porous Media 87, 653-664 (2011). https://doi. org/10.1007/s11242-010-9696-3

172. Cheraghian, G.: Effect of nano titanium dioxide on heavy oil recovery during polymer flooding. Pet. Sci. Technol. 34, 633-641 (2016). https://doi.org/10.1080/10916466.2016.1156125

173. Rezaei, A., Abdi-Khangah, M., Mohebbi, A., Tatar, A., Mohammadi, A.H.: Using surface modified clay nanoparticles to improve rheological behavior of Hydrolyzed Polyacrylamide (HPAM) solution for enhanced oil recovery with polymer flooding. J. Mol. Liq. 222, 1148-1156 (2016). https://doi.org/10.1016/j.molli q.2016.08.004

174. Zheng, C., Cheng, Y., Wei, Q., Li, X., Zhang, Z.: Suspension of surface-modified nano- $\mathrm{SiO}_{2}$ in partially hydrolyzed aqueous solution of polyacrylamide for enhanced oil recovery. Colloids Surf. A Physicochem. Eng. Asp 524, 169-177 (2017). https:// doi.org/10.1016/j.colsurfa.2017.04.026

175. Haeri, M.F.: Experimental evaluation of surfactant-based nanofluids on wettability alteration and oil recovery. A doctoral dissertation submitted to Craft \& Hawkins Department of Petroleum Engineering, Louisiana State University (2018)

176. Zhao, M., Lv, W., Li, Y., Dai, C., Wang, X., Zhou, H., et al.: Study on the synergy between silica nanoparticles and surfactants for enhanced oil recovery during spontaneous imbibition. J. Mol. Liq. 261, 373-378 (2018). https://doi.org/10.1016/j.molli q.2018.04.034

177. Pei, H., Zhang, G., Ge, J., Zhang, J., Zhang, Q.: Investigation of synergy between nanoparticle and surfactant in stabilizing oilin-water emulsions for improved heavy oil recovery. Colloids Surf. A Physicochem. Eng. Asp 484, 478-484 (2015). https:// doi.org/10.1016/j.colsurfa.2015.08.025

178. Mobaraki, S., Zakavi, M., Mahmoodi, O., Omidvar Sorkhabadi, M., Khalilinezhad, S.S., Shiri, Torkmani R.: An experimental study on the mechanisms of enhancing oil recovery by nanoparticles-assisted surfactant flood. Geosyst. Eng. (2018). https://doi. org/10.1080/12269328.2018.1515670

179. Bazazi, P., Gates, I.D., Sanati Nezhad, A., Hejazi, S.H.: Silica-based nanofluid heavy oil recovery a microfluidic approach. SPE Can. Heavy Oil Tech. Conf. (2017). https://doi. org/10.2118/185008-ms

180. Vatanparast, H., Javadi, A., Bahramian, A.: Silica nanoparticles cationic surfactants interaction in water-oil system. Colloids Surf. A Physicochem. Eng. Asp 521, 221-230 (2017). https:// doi.org/10.1016/j.colsurfa.2016.10.004

181. Pichot, R., Spyropoulos, F., Norton, I.T.: Competitive adsorption of surfactants and hydrophilic silica particles at the oil-water interface: interfacial tension and contact angle studies. J. Colloid Interface Sci. 377, 396-405 (2012). https://doi.org/10.1016/j. jcis.2012.01.065

182. Zargartalebi, M., Barati, N., Kharrat, R.: Influences of hydrophilic and hydrophobic silica nanoparticles on anionic surfactant properties: interfacial and adsorption behaviors. J. Pet. Sci. Eng. 119, 36-43 (2014). https://doi.org/10.1016/j.petrol.2014.04.010

183. Suleimanov, B.A., Ismailov, F.S., Veliyev, E.F.: Nanofluid for enhanced oil recovery. J. Pet. Sci. Eng. 78, 431-437 (2011). https ://doi.org/10.1016/j.petrol.2011.06.014

184. Giraldo, J., Benjumea, P., Lopera, S., Cortés, F.B., Ruiz, M.A.: Wettability alteration of sandstone cores by alumina-based nanofluids. Energy Fuels 27, 3659-3665 (2013). https://doi. org/10.1021/ef4002956 
185. Ahmadi, M.A., Shadizadeh, S.R.: Induced effect of adding nano silica on adsorption of a natural surfactant onto sandstone rock: experimental and theoretical study. J. Pet. Sci. Eng. 112, 239-247 (2013). https://doi.org/10.1016/j.petrol.2013.11.010

186. Mohajeri, M., Hemmati, M., Shekarabi, A.S.: An experimental study on using a nanosurfactant in an EOR process of heavy oil in a fractured micromodel. J. Pet. Sci. Eng. 126, 162-173 (2015). https://doi.org/10.1016/j.petrol.2014.11.012

187. Sharma, T., Iglauer, S., Sangwai, J.S.: Silica nanofluids in an oilfield polymer polyacrylamide: interfacial properties, wettability alteration, and applications for chemical enhanced oil recovery. Ind. Eng. Chem. Res. 55, 12387-12397 (2016). https://doi. org/10.1021/acs.iecr.6b03299

188. Karimi, A., Fakhroueian, Z., Bahramian, A., Pour Khiabani, N., Darabad, J.B., Azin, R., et al.: Wettability alteration in carbonates using zirconium oxide nanofluids: EOR implications. Energy Fuels 26, 1028-1036 (2012). https://doi.org/10.1021/ef201475u

189. Bayat, A.E., Rajaei, K., Junin, R.: Assessing the effects of nanoparticle type and concentration on the stability of $\mathrm{CO}_{2}$ foams and the performance in enhanced oil recovery. Colloids Surf. A Physicochem. Eng. Asp 511, 222-231 (2016). https://doi. org/10.1016/j.colsurfa.2016.09.083

190. Espinoza, D.A., Caldelas, F.M., Johnston, K.P., Bryant, S.L., Huh, C.: Nanoparticle-stabilized supercritical $\mathrm{CO}_{2}$ foams for potential mobility control applications. In: Present. SPE Improv. Oil Recover. Symp. 24-28 April. Tulsa, Oklahoma, USA, Society of Petroleum Engineers, pp. 1-13 (2010). https://doi. org/10.2118/129925-ms

191. Yu, J., Liu, N., Li, L., Lee, R.L.: Generation of nanoparticle-stabilized supercritical $\mathrm{CO}_{2}$ foams. In: C. Pap. Present. Carbon Manag. Technol. Conf. 7-9 February, Orlando, Florida, USA, Orlando, Florida, USA: Carbon Management Technology Conference, pp. 1-11 (2012). https://doi.org/10.7122/150849-ms

192. Yang, W., Wang, T., Fan, Z.: Highly stable foam stabilized by alumina nanoparticles for EOR: effects of sodium cumene sulfonate and electrolyte concentrations. Energy Fuels 31, 9016-9025 (2017). https://doi.org/10.1021/acs.energyfuels.7b01248

193. Mo, D., Yu, J., Liu, N., Lee, R.L.: Study of the effect of different factors on nanoparticle-stabilized $\mathrm{CO}_{2}$ foam for mobility control. In: SPE Annu. Tech. Conf. Exhib. 8-10 October, San Antonio, Texas, USA, Society of Petroleum Engineers, pp. 1-11 (2012). https://doi.org/10.2118/159282-ms

194. Risal, A.R., Manan, M.A., Yekeen, N., Azli, N.B., Samin, A.M., Tan, X.K.: Experimental investigation of enhancement of carbon dioxide foam stability, pore plugging, and oil recovery in the presence of silica nanoparticles. Pet. Sci. (2018). https://doi. org/10.1007/s12182-018-0280-8

195. Yu, J., An, C., Mo, D., Liu, N., Lee, R.L.: Foam mobility control for nanoparticle-stabilized supercritical $\mathrm{CO}_{2}$ foam. In: SPE Improv. Oil Recover. Symp. 14-18 April. Tulsa, Oklahoma, USA, Tulsa, Oklahoma, USA: Society of Petroleum Engineers, pp. 1-13 (2012). https://doi.org/10.2118/153336-ms

196. Kalyanaraman, N., Arnold, C., Gupta, A., Tsau, J.S., Ghahfarokhi, R.B.: Stability improvement of $\mathrm{CO}_{2}$ foam for enhanced oil-recovery applications using polyelectrolytes and polyelectrolyte complex nanoparticles. J. Appl. Polym. Sci. 134(1-15), 44491 (2017). https ://doi.org/10.1002/app.44491

197. Aroonsri, A., Worthen, A.J., Hariz, T., Johnston, K.P., Huh, C., Bryant, S.L.: Conditions for generating nanoparticle-stabilized $\mathrm{CO}_{2}$ foams in fracture and matrix flow. In: SPE Annu. Tech. Conf. Exhib. 30 Sept. October, New Orleans, Louisiana, USA, New Orleans, Louisiana, USA: Society of Petroleum Engineers, pp. 1-19 (2013). https://doi.org/10.2118/166319-ms

198. Singh, R., Gupta, A., Mohanty, K.K., Huh, C., Lee, D., Cho, H.: Fly ash nanoparticle-stabilized $\mathrm{CO}_{2}$-in-water foams for gas mobility control applications. In: SPE Annu. Tech. Conf. Exhib. 28-30 Sept.
Houston, Texas, USA, Houston, Texas, USA: Society of Petroleum Engineers, pp. 1-13 (2015). https://doi.org/10.2118/175057-ms

199. Manan, M.A., Farad, S., Piroozian, A., Esmail, M.J.A.: Effects of nanoparticle types on carbon dioxide foam flooding in enhanced oil recovery. Pet. Sci. Technol. 33, 1286-1294 (2015). https://doi. org/10.1080/10916466.2015.1057593

200. Kim, I., Worthen, A.J., Johnston, K.P., DiCarlo, D.A., Huh, C.: Size-dependent properties of silica nanoparticles for Pickering stabilization of emulsions and foams. J Nanopart. Res 18, 82 (2016). https://doi.org/10.1007/s11051-016-3395-0

201. Singh, R., Mohanty, K.K.: Foams stabilized by in-situ surface-activated nanoparticles in bulk and porous media. SPE J. 21, 121-130 (2016). https://doi.org/10.2118/170942-PA

202. Wang, S., Chen, C., Kadum, M.J., Shiau, B.-J., Harwell, J.H.: Enhancing foam stability in porous media by applying nanoparticles. J. Dispers. Sci. Technol. 39, 734-743 (2018). https://doi. org/10.1080/01932691.2017.1388175

203. Singh, R., Mohanty, K.K.: Foam flow in a layered, heterogeneous porous medium: a visualization study. Fuel 197, 58-69 (2017). https://doi.org/10.1016/j.fuel.2017.02.019

204. Yekeen, N., Manan, M.A., Idris, A.K., Samin, A.M., Risal, A.R.: Experimental investigation of minimization in surfactant adsorption and improvement in surfactant-foam stability in presence of silicon dioxide and aluminum oxide nanoparticles. J. Pet. Sci. Eng. 159, 115-134 (2017). https://doi.org/10.1016/j.petrol.2017.09.021

205. Singh, R., Mohanty, K.K.: Nanoparticle-stabilized foams for hightemperature, high-salinity oil reservoirs. In: Present. SPE Annu. Tech. Conf. Exhib. 9-11 October, San Antonio, Texas, USA, San Antonio, Texas, USA: Society of Petroleum Engineers, pp. 1-15 (2017). https://doi.org/10.2118/187165-ms

206. Esfandyari Bayat, A., Junin, R., Samsuri, A., Piroozian, A., Hokmabadi, M.: Impact of metal oxide nanoparticles on enhanced oil recovery from limestone media at several temperatures. Energy Fuels 28, 6255-6266 (2014). https://doi.org/10.1021/ef5013616

207. Shahrabadi, A., Bagherzadeh, H., Roostaie, A., Golghanddashti, H.: Experimental investigation of HLP nanofluid potential to enhance oil recovery: a mechanistic approach. In: SPE Int Oilf Nanotechnol Conf Exhib 12-14 June, Noordwijk, The Netherlands, pp. 1-9 (2012). https://doi.org/10.2118/156642-ms

208. Ehtesabi, H., Ahadian, M.M., Taghikhani, V., Ghazanfari, M.H.: Enhanced heavy oil recovery in sandstone cores using $\mathrm{TiO}_{2}$ nanofluids. Energy Fuels 28, 423-430 (2014). https://doi.org/10.1021/ ef $401338 \mathrm{c}$

209. Roustaei, A., Saffarzadeh, S., Mohammadi, M.: An evaluation of modified silica nanoparticles' efficiency in enhancing oil recovery of light and intermediate oil reservoirs. Egypt J. Pet. 22, 427-433 (2013). https://doi.org/10.1016/j.ejpe.2013.06.010

210. Hendraningrat, L., Torsæter, O.: Metal oxide-based nanoparticles: revealing their potential to enhance oil recovery in different wettability systems. Appl. Nanosci. 5, 181-199 (2015). https://doi. org/10.1007/s13204-014-0305-6

211. Zhang, H., Nikolov, A., Wasan, D.: Enhanced oil recovery (EOR) using nanoparticle dispersions: underlying mechanism and imbibition experiments. Energy Fuels 28, 3002-3009 (2014). https://doi. org/10.1021/ef500272r

212. Salem Ragab, A.M., Hannora, A.E.: A comparative investigation of nano particle effects for improved oil recovery-experimental work. In: Present. SPE Kuwait Oil Gas Show Conf. 11-14 October, Mishref, Kuwait, Society of Petroleum Engineers, pp. 1-16 (2015). https://doi.org/10.2118/175395-ms

213. Tarek, M., El-Banbi, A.H.: Comprehensive investigation of effects of nano-fluid mixtures to enhance oil recovery. In: SPE North Africa Tech. Conf. Exhib. 14-16 Sept. Cairo, Egypt, Cairo, Egypt: Society of Petroleum Engineers, pp. 1-10 (2015). https:// doi.org/10.2118/175835-ms 
214. Li, S., Hendraningrat, L., Torsaeter, O.: Improved oil recovery by hydrophilic silica nanoparticles suspension: 2-phase flow experimental studies. In: Present. Int. Pet. Technol. Conf. 26-28 March, Beijing, China, International Petroleum Technology Conference, pp. 1-15 (2013). https://doi.org/10.2523/iptc-16707-ms

215. Li, S., Genys, M., Wang, K., Torsæter, O.: Experimental study of wettability alteration during nanofluid enhanced oil recovery process and its effect on oil recovery. In: Present. SPE Reserv. Characterisation Simul. Conf. Exhib. 14-16 Sept. Abu Dhabi, UAE, Society of Petroleum Engineers, pp. 1-11 (2015). https:// doi.org/10.2118/175610-ms

216. Roustaei, A., Bagherzadeh, H.: Experimental investigation of $\mathrm{SiO}_{2}$ nanoparticles on enhanced oil recovery of carbonate reservoirs. J. Pet. Explor. Prod. Technol. 5, 27-33 (2015). https://doi. org/10.1007/s13202-014-0120-3
217. Maghzi, A., Mohammadi, S., Ghazanfari, M.H., Kharrat, R., Masihi, M.: Monitoring wettability alteration by silica nanoparticles during water flooding to heavy oils in five-spot systems: a porelevel investigation. Exp. Therm. Fluid. Sci. 40, 168-176 (2012). https://doi.org/10.1016/j.expthermflusci.2012.03.004

218. El-Diasty, A.I.: The potential of nanoparticles to improve oil recovery in Bahariya formation, Egypt: an experimental study. In: Present SPE Asia Pacific Enhanc Oil Recover Conf 11-13 August, Kuala Lumpur, Malaysia, pp. 1-14 (2015). https://doi. org/10.2118/174599-ms

219. Johnson, K.E.: What's an ionic liquid? Electrochem. Soc. Interface 5, 38-41 (2007)

Publisher's Note Springer Nature remains neutral with regard to jurisdictional claims in published maps and institutional affiliations. 